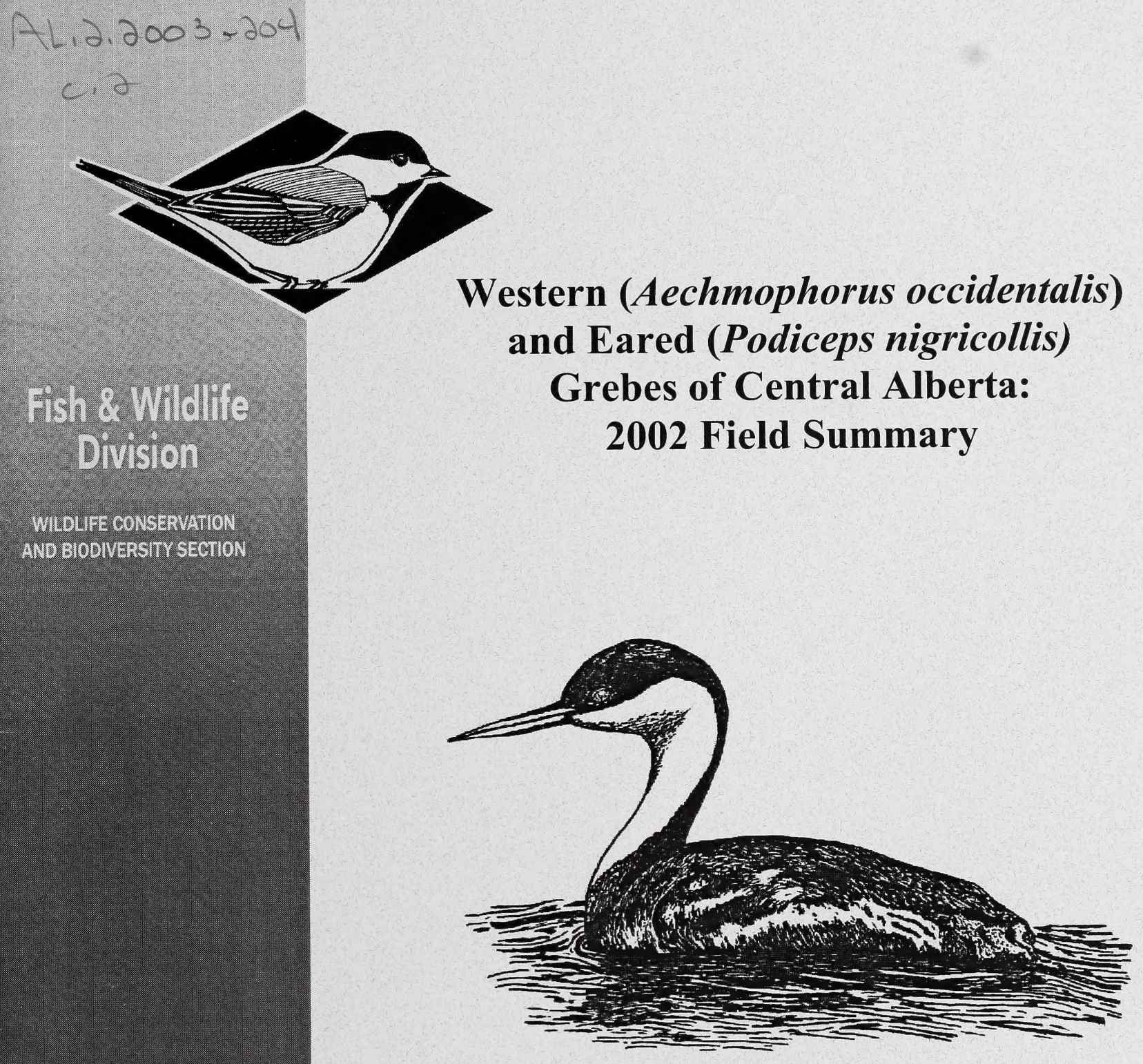

Alberta Species at Risk Report No. 60 
Digitized by the Internet Archive in 2016 


\section{Western (Aechmophorus occidentalis) and Eared (Podiceps nigricollis) \\ Grebes of Central Alberta: 2002 Field Summary}

Stephen Hanus

Lisa Wilkinson

and

Hugh Wollis

Alberta Species at Risk Report No. 60

December 2002

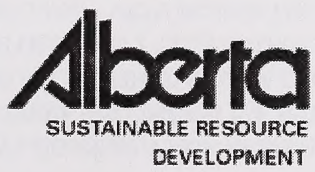


Publication No.: I/091

ISBN: 0-7785-2333-0 (Printed Edition)

ISBN: 0-7785-2334-0 (On-line Edition)

ISSN: 1496-7219 (Printed Edition)

ISSN: 1496-7146 (On-line Edition)

Illustration: Stephen Hanus

For copies of this report, contact:

Information Centre - Publications

Alberta Environment / Alberta Sustainable Resource Development

Main Floor, Great West Life Building

9920108 Street

Edmonton, Alberta, Canada T5K 2M4

Telephone (780) 422-2079

\section{OR}

Information Service

Alberta Environment / Alberta Sustainable Resource Development

\#100, 311512 Street NE

Calgary, Alberta, Canada T2E 7J2

Telephone (403) 297-3362

\section{OR}

Visit our website at:

http://www3.gov.ab.ca/srd/fw/riskspecies/

This publication may be cited as:

Hanus, S., L. Wilkinson and H. Wollis. 2002. Western (Aechmophorus occidentalis) and Eared (Podiceps nigricollis) Grebes of Central Alberta: 2002 field summary. Alberta Sustainable Resource Development, Fish and Wildlife Division, Alberta Species at Risk Report No. 60. Edmonton, AB. 


\section{TABLE OF CONTENTS}

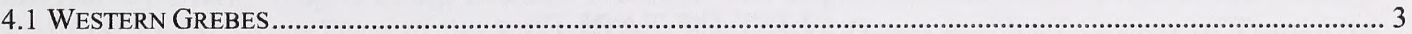

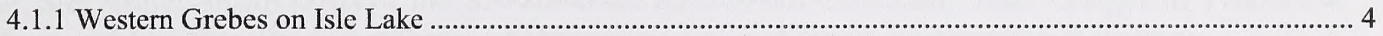

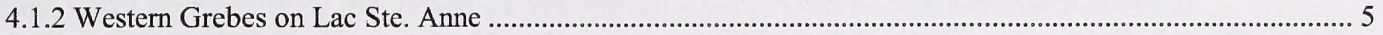

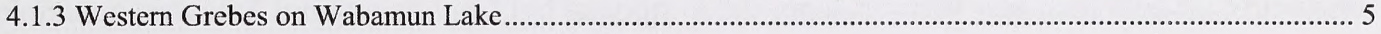

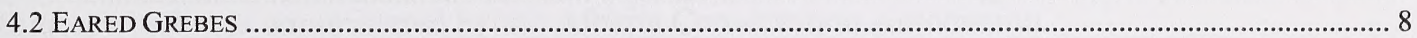

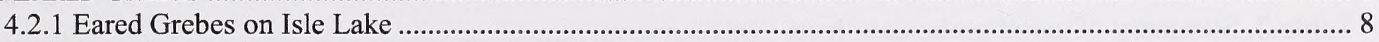

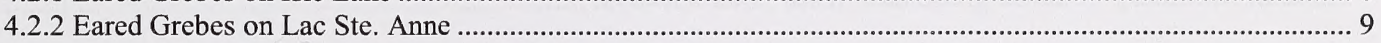

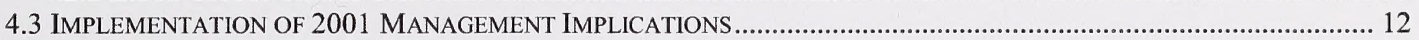

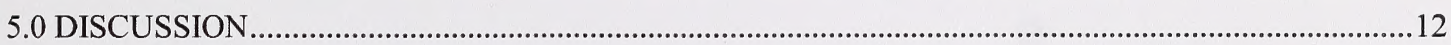

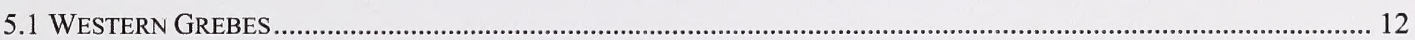

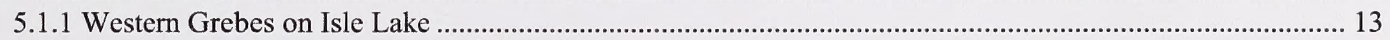

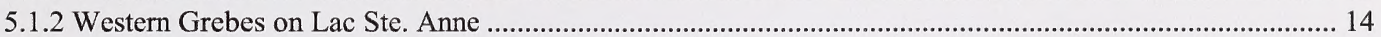

5.1.3 Western Grebes on Wabamun Lake................................................................................................. 15

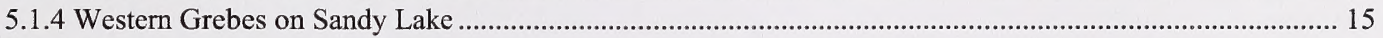

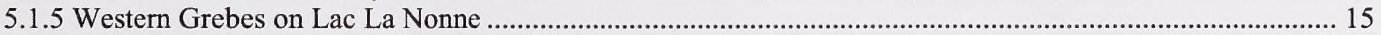

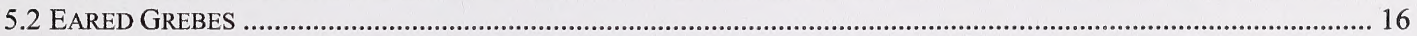

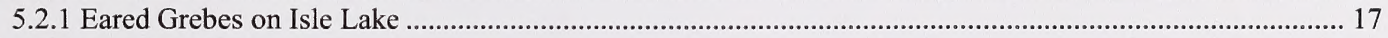

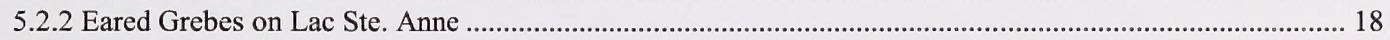

6.0 MANAGEMENT IMPLICATIONS AND FUTURE DIRECTION ............................................... 18

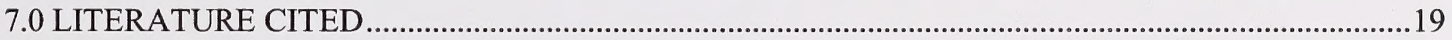

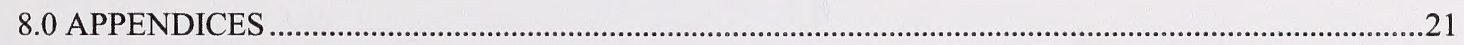

APPENDIX 1 MAP OF Alberta, THE StONy Plain StUdy AREA AND DISTRIBUTION OF GREBE COLONIES ................... 22

APPENDIX 2 WESTERN AND EARED GREBE OBSERVATIONS ON LAKES SURVEYED IN 2002 ..................................... 23

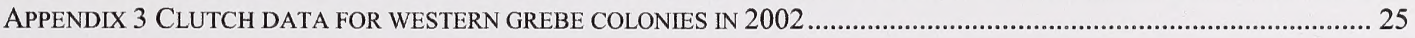

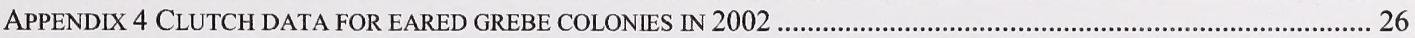

APPENDIX 5 WESTERN GREBE NEST QUALITY DURING POST BREEDING SEASON TOTAL NEST COUNTS .......................... 27

APPENDIX 6 WESTERN GREBE SIGN DEVELOPED FOR LAKES WITHIN THE STONY PLAIN STUDY AREA............................ 28

APPENDIX 7 SHORELINE HABITAT SIGN DEVELOPED FOR LAKES WITHIN THE STONY PLAIN STUDY AREA....................... 29

APPENDIX 8 LOCATIONS AND STYLE OF SIGNS ESTABLISHED WITHIN THE STONY PLAIN STUDY AREA........................... 30

APPENDIX 9 SPECIFICATIONS FOR WESTERN GREBE AND SHORELINE HABITAT CONSERVATION SIGNS ......................... 31

APPENDIX 10 GREBE AND SHORELINE HABITAT CONSERVATION PRESENTATIONS GIVEN TO THE PUBLIC ....................... 32 


\section{LIST OF FIGURES}

Figure 1. Mean clutch sizes for western grebe colonies in the Stony Plain area, Alberta............................

Figure 2. Proportion of active nests for western grebe colonies in the Stony Plain area, Alberta....................7

Figure 3. Mean clutch sizes for eared grebe colonies in the Stony Plain area, Alberta................................11

Figure 4. Proportion of active nests for eared grebe colonies in the Stony Plain area, Alberta. ....................11

\section{LIST OF TABLES}

Table 1. Summary of western grebe data from 2002 surveys. 6

Table 2. Summary of eared grebe data from 2002 surveys 10 


\section{ACKNOWLEDGEMENTS}

We would like to recognize the individuals who assisted with this project. Field data collection was made possible with the help of Jan Ficht and Julie Herbert of Alberta Sustainable Resource Development, Gordon Eadie of the Lesser Slave Lake Bird Observatory, Lisa Pristley of Bird Studies Canada, Marcel Gotier, Cathy Hanus, and Jacques Sirois. We sincerely appreciate the logistical assistance provided to us by Francesco Marchet, a Conservation Officer with Alberta Sustainable Resource Development. Patricia Schultz and the staff of William Huff Advertising Ltd. did a wonderful job producing the signs we developed, and their expertise was greatly appreciated. For their assistance in establishing signs at boat launches within our study area, we would like to thank Harvey Clark, Wayne King, Richard Neufeld, Ted Taphorne, and Kieth Yuill of the County of Lac Ste. Anne; Susan Dzus of the S.V. of Seba Beach; Gil Goerz and Ralf Leriger of TransAlta Utilities; and Lee Randle of the Town of Wabamun Lake. Alberta Sustainable Resource Development provided funding and in-kind support. Additional funding was provided by TransAlta Utilities, which was administered by the Alberta Conservation Association. 


\section{EXECUTIVE SUMMARY}

This project is in its second year, and is designed to monitor population trends and reproductive success of western grebes (Aechmophorus occidentalis) and eared grebes (Podiceps nigricollis) within the Stony Plain study area, Alberta. Surveys are projected to span a five year period, and the results will be used in conservation and management efforts. This project also provides information to support lake habitat conservation and public education. Survey protocols developed by this project are applicable to other regions in Alberta. In 2002, surveying effort was focused on the primary western and eared grebe populations identified in the initial year of this project. Ground nest surveys were the primary means used to estimate adult population sizes; however, this technique was modified slightly from 2001. Instead of conducting a single total nest count at the predicted peak of the nesting season, we surveyed each colony along a sample transect several times during the nesting season. Total nest counts were conducted near end or after the nesting period, and the results from which were used to derive a total breeding adult population estimate.

We estimated the regional population of western grebes to be approximately 2611 adults on six lakes. Nesting colony locations were similar to the findings from 2001 surveys. Western grebes inhabiting Wabamun Lake and Lac Ste. Anne continue to be the dominant populations in the study area, representing $57.8 \%$ and $30.7 \%$ of the regional population, respectively. The Wabamun Lake colony increased in size by nearly $35 \%$, whereas the Lac Ste. Anne colony declined by nearly $37 \%$. The Isle Lake population size remained relatively stable from 2001 to 2002. One new population of western grebes was identified on Sandy Lake, where breeding was likely occurring but not confirmed. The peak nesting season in 2002 occurred between June 10 and June 19 survey dates. Assuming that timing of nesting was similar between years, ground nest surveys in 2001 occurred slightly after the peak nesting season. In 2002, maximum mean clutch sizes for western grebe colonies ranged from 2.71 to 2.95 eggs/nest ( $n=581$ nests, three colonies), which is within the range reported in the literature. The maximum proportion of active nests ranged from $89.8 \%$ to $95.0 \%$. The Wabamun Lake colony continues to show signs of poor nesting success, which we now believe to be attributed to high rates of corvid nest depredation. This is a major concern since this colony is ranked nationally significant.

Surveys for eared grebes were conducted on 13 lakes, of which 10 lakes had eared grebe populations for a conservative overall population estimate of 8633 adults. Although our survey of the study area was not as thorough as in 2001 (i.e. 52 lakes surveyed), the 2002 overall population estimate was higher than estimate of the previous year (7632 adults). The George Lake eared grebe population was the largest (5000+ adults), up 38\% from 2001. Nesting was confirmed on five lakes, but due to logistical constraints we only assessed nesting success of the Isle Lake and Lac Ste. Anne colonies. The mean clutch size for eared grebes ranged from 2.55 eggs/nest to 3.46 eggs/nest, and the proportion of nests ranged from $81 \%$ to $100 \%$ throughout the survey period. The George Lake colony continues to be nationally important to eared grebes, and with the large influx of eared grebes on Isle Lake this population also ranks as nationally important. It is apparent from our surveys that eared grebe population sizes and colony locations are highly variable, demonstrating that they rely on a network of waterbodies to sustain their regional population. Eared grebes also appear to prefer shallow and undeveloped lakes and generally avoid large and developed waterbodies. Finally, the Stony Plain area may be particularly important in times of drought, as was observed in 2002, by attracting eared grebes from other regions of the province with the availability of suitable nesting sites. 


\subsection{INTRODUCTION}

Western grebes (Aechmophorus occidentalis) and eared grebes (Podiceps nigricollis) are part of the family Podicipedidae, an ancient species of diving specialists that rarely fly except to migrate. These grebe species are colonial nesting waterbirds that build precarious floating nests of aquatic vegetation either secured to emergent vegetation or free-floating. Both species have wide distributions across western and central North America, with some colonies having thousands of nests.

As with many top predators in ecosystems highly impacted by humans, western and eared grebes are sensitive to these impacts and could become threatened over the long-term. Currently in Alberta, western grebes are listed as 'sensitive', while eared grebes are listed as 'secure' (Alberta Sustainable Resource Development 2000). This project was developed due to the relatively sparse data available to quantify these rankings. In the process, surveying protocols have been developed and refined, population trend, distribution and measures of reproductive success within the study area are being monitored, and specific threats to western and eared grebe populations have been identified.

The information presented in this report represents the findings from the second year of surveying western and eared grebes within the Stony Plain study area in Alberta (Appendix 1). Baseline research and data for this area are presented in two reports by Hanus et al. (2002a, 2002b). A synthesis of provincial data for western and eared grebes is provided in Hanus (2002).

In 2002 our objectives were to:

1) Monitor the primary populations of western and eared grebes in the Stony Plain study area (Appendix 1) as identified in 2001. The monitoring emphasis was for western grebes due to their 'sensitive' status in Alberta;

2) Measure the reproductive success of selected western and eared grebe colonies;

3) Inventory as many other lakes as possible within the study area to identify those with active western and eared grebe populations, and locate new colonies; and

4) Implement management recommendations presented in Hanus et al. (2002a).

\subsection{STUDY AREA}

A detailed description of the Stony Plain study area is provided in Hanus et al. (2002a). Briefly, this area is located in central Alberta (Appendix 1), and includes the counties of Barrhead, Lac Ste. Anne, Parkland, and Westlock. The legal land description for the study area includes townships 48 to 66 and ranges 23 to 28 west of the fourth meridian, and townships 48 to 66 and ranges one to nine west of the fifth meridian (i.e. between $53^{\circ}$ and $55^{\circ}$ north latitude, and $113^{\circ}$ and $115^{\circ}$ west longitude). The north/south and east/west maximum distances are approximately $143 \mathrm{~km}$ and $135 \mathrm{~km}$, respectively, while the total area is $11592.6 \mathrm{~km}^{2}$. Specific details of lakes with active and/or historic grebe breeding colonies are presented in Hanus et al. (2002b).

The study area is located within the parkland and boreal forest natural regions (Alberta Environmental Protection 1994). It is within an agricultural dominated landscape where much of the original vegetation has been cleared for agricultural, urban, and industrial development. The proximity of the study area to several urban centres, such as the city of Edmonton, make many of these lakes attractive for recreation and cottage development. Lakes are generally meso- to hypereutrophic. 


\subsection{METHODS}

Field surveys occurred between June 10, 2002 and July 12, 2002 to coincide with the peak nesting period for western and eared grebes. The focus in 2002 was to monitor the primary colonies identified by Hanus et al. (2002a), rather than conducting a broad inventory throughout the study area. Nevertheless, lakes with smaller populations and new sites were also surveyed whenever the opportunity arose.

In order to survey populations of western and eared grebes and to locate their nesting colonies, we used the meandering shoreline boat technique as described in Hanus et al. (2002a). Lakes surveyed in this manner included Big Lake (east basin), Brock Lake, Lac Ste. Anne (west basin), Majeau Lake (east basin), and Sandy Lake (Appendix 1). Several lakes or portions of lakes that were not suited to boating were surveyed using the shoreline telescope survey (Hanus et al. 2002a), and included Arthur Lake, Majeau Lake (west basin), unnamed lake south of Lac Ste. Anne, and the unnamed lake south of Sandy Lake (Appendix 1).

Ground nest surveys (Hanus et al. 2002a) were conducted on Isle Lake, Lac Ste. Anne, and Wabamun Lake. This technique was slightly modified according to the recommendations outlined in Hanus et al. (2002a). Instead of surveying an entire colony only once at the presumed peak of the nesting season, several surveys of a subset of nests were conducted throughout the nesting period. Ground nest surveys were conducted along a single transect through the approximate centre of each colony. The transect routes were consistent for each survey, but were lengthened if colonies grew in size between surveys. For each survey, two observers were spaced approximately six meters apart, for a total transect width of approximately $12 \mathrm{~m}$. Ground nest surveys were conduced once every seven to nine days for a total of four to five ground nest surveys per colony. The implementation of these recommended modifications has two main benefits. The first benefit is that repeated surveys enable us to achieve an improved index of maximum egg production thereby addressing the challenges of surveying asynchronous egg laying birds. The second benefit is that disturbance to nesting birds is minimised during surveys since time spent within the colonies is decreased.

Total nest counts were conducted once the majority of nests were abandoned to ascertain the complete size of the colonies. We used a target of $<10 \%$ active nests within the colony as being suitable for total nest counts. During the total nest count surveys, we recorded the state of nest decay as intact, partially floating, or sunken, to derive an index of time since nest abandonment. An eared grebe nest count based from a canoe was conducted on George Lake; however, due to logistical constraints clutch measurements could not be gathered.

Having surveyors directly within the colony during the breeding season enabled them to record several measures of reproductive success. We recorded clutch sizes, the presence of egg fragments from either successful hatching events or egg depredation, and the number of chicks observed. Distinguishing between successful hatching events and egg depredation was often difficult. Shell fragments were identified as successful hatching events if the egg membrane was present in the nest and/or the egg was broken into two neat pieces, one being generally larger than the other (Baicich and Harrison 1997). Shell fragments were identified as a depredation event if the egg had a distinguishable hole in its side with the undeveloped embryo either partially or completely consumed, and no egg membranes were present in the nest. Active nests were considered any nest with eggs 
and/or chicks at the time of the survey. Empty nests were included within the total count of nests for each colony, and nests that appeared to be abandoned and/or damaged were noted as such. A mean and modal clutch size was determined from each ground nest survey, and calculated using only nests with at least one egg and/or chick. While in the colonies we also made general site notes describing the habitat, which included aquatic vegetation species composition, colony length and width measurements, and water depths.

Colony locations were recorded using Garmin ${ }^{\mathrm{TM}}$ model $12 \mathrm{XL}$ handheld global positioning (GPS) units set to NAD 83. For larger colonies, several GPS locations were recorded along their perimeter to provide an index of size.

Observations of other waterbirds were also recorded during field surveys, and will be summarised in a future report.

\subsection{RESULTS}

We surveyed a total of 13 lakes in 2002 and although this is considerably less than the 52 lakes surveyed in 2001, they represent nearly all lakes with primary western and eared grebe populations identified by Hanus et al. (2002a). A summary table of results, survey dates, and methods used for each lake surveyed in 2002 is provided in Appendix 2. Although some lakes were surveyed several times using different techniques, we only provide one set of results from the surveys we considered most accurate (Appendix 2). A summary of population and colony data is provided in Table 1 for western grebes, and Table 2 for eared grebes. Clutch data for western and eared grebes are provided in Appendices 3 and 4, respectively.

\subsection{Western Grebes}

Sizeable western grebe populations continue to inhabit Lac Ste. Anne, Wabamun Lake, and Isle Lake. Of special interest is the discovery of a population inhabiting Sandy Lake. Breeding here was likely, but not confirmed. Lac La Nonne continues to have a small population, but no nesting sites were confirmed even with intensive reconnaissance of nesting habitat throughout the lake. A small number of western grebes were observed on Brock Lake, which is a new siting for this waterbody, but nesting was not confirmed. Although we observed three western grebes on Thunder Lake in 2001 (Hanus et al. 2002a), we did not re-survey this lake in 2002 due to logistical constraints.

Within the study area (Appendix 1) we estimated a total of 2611 adult western grebes, and three colonies accounted for 1218 nests. The largest adult western grebe populations and breeding colonies were observed on Wabamun Lake and Lac Ste. Anne, which represented $57.8 \%$ and $30.7 \%$ of the regional population, respectively.

All western grebe colonies had relatively similar measures of reproductive success in 2002 (Table 1; Figures 1 and 2). The peak nesting season for all colonies occurred between June 10 and June 19 , after which there was a sharp decline, and by July 4 nesting was nearly complete (Table 1; Figure 1). The highest mean clutch size among the colonies was observed on Isle Lake (2.95 eggs/nest), but was closely followed by Lac Ste. Anne (2.84 eggs/nest) and Wabamun Lake (2.71 eggs/nest; Table 1; Figure 1). Although these maximum mean clutch values are higher than the maximum values 
reported last year (Hanus et al. 2002a), they are more similar when compared on the same survey dates (Figure 1). The maximum mode clutch size reached three eggs/nest for each western grebe colony, and these values also declined after June 19 (Table 1). All colonies had high proportions of active nests (i.e. $89.8 \%$ to $96.0 \%$ ) early in the nesting season (Table 1; Figure 2), followed by a decline after June 19. However, there were differences in the rate of nest abandonment. The Wabamun Lake colony had the most rapid decline, the Isle Lake colony had the most gradual decline, and the Lac Ste. Anne colony had a moderate decline (Table 1; Figure 2). Additional clutch data for western grebes is presented in Appendix 3.

\subsubsection{Western Grebes on Isle Lake}

The western grebe population on Isle Lake is the only one in the study area to nest adjacent to islands: all other colonies in the study area are adjacent to lakeshores. Western grebes nested in bulrush surrounding two small islands, which we termed the 'west island colony location' and the 'east island colony location'. These sites are in close proximity to one another (separated by $700 \mathrm{~m}$ ) and have relatively similar habitat characteristics, so both nesting locations are regarded as a single colony. This population was the only one in the study area to have had a noticeable change in nesting location between years. Most nesting pairs in the west island colony location nested approximately $400 \mathrm{~m}$ from their 2001 nesting area (i.e. east side of the island) to the west side of the island. As well, only two western grebe pairs nested in the east island colony during the 2002 breeding season where in 2001 there were 17 pairs. Interspecific brood parasitism from eared grebes was relatively common in the Isle Lake western grebe colony: on June 10, zero out of 27 nests were parasitized; on June 19, 12 out of 59 nests were parasitized with one to 11 eggs; on June 26, seven out of 62 nests were parasitized with one to three eggs; and on July 3 , nine out of 40 nests were parasitized with one to four eggs. Besides eared grebes, other birds found nesting at the east and west island colony locations included coots, common terns, Forster's terns, and yellow-headed blackbirds. No dead western grebes were observed in the colony in 2002.

Due to the small size of these colonies, each ground survey conducted was very nearly a total count. On June 26, 2002 the maximum number of nests counted was 62, for a breeding population of approximately 124 individuals. These values were down slightly from 2001 , when the total number of nests counted was 77, for a breeding population of approximately 154 individuals (Hanus et al. 2002a). When comparing the reported mean clutch size from June 14, 2001 to the extrapolated value for the same day in 2002 (Figure 1), the values differed only slightly from approximately 2.8 to 2.9 eggs/nest, respectively. The maximum mean clutch size of 2.95 eggs/nest was observed on June 10 , 2002 , which was the highest among colonies surveyed in the study area. By the last survey on July 3 , 2002 the mean clutch size declined to 1.97 eggs/nest, but was still higher than the other western grebe colonies in the study area (Table 1; Figure 1). Among all the colonies surveyed, the Isle Lake colony had the slowest rate of nest abandonment (Table 1; Figure 1): the maximum proportion of active nests occurred on June 19 (i.e. $89.8 \%$ ) and by July 4 the proportion of active nests only decreased to $77.5 \%$. The sample size of nests did, however, decline from 62 nests on June 26 to 40 nests on July 3 (Table 1). The evidence of egg depredation within Isle Lake colony was lowest in the study area, with only four depredated eggs observed (Appendix 3). 


\subsubsection{Western Grebes on Lac Ste. Anne}

Western grebes on Lac Ste. Anne nested in the same location as observed in 2001 (Hanus et al. 2002a,b), but a satellite nesting area approximately one kilometre to the north was no longer active in 2002. The overall lake population appears to have declined considerably. We counted a total of 401 nests, for a breeding population of 802 individuals in 2002 (Table 1), whereas in 2001 we counted 634 nests for a breeding population of 1268 individuals (Hanus et al. 2002a,b). This represents a decline of nearly $37 \%$. Most of the nests at the time of the total nest count were in relatively good condition (Appendix 5), suggesting that the timing of the survey was good.

The maximum mean clutch size was observed on June 19, 2002 after which there was a steep decline to 1.59 eggs/nest on July 3 followed by a slight increase to 1.74 eggs/nest on July 12 (Table 1; Figure 1). The mean clutch size observed on June 22, 2001 was lower by over 0.2 eggs/nest than the extrapolated value observed in 2002 (Figure 1). Between June 11 and 19, 2002, there was a high proportion of active nests, after which point there was a relatively steady decline to the last survey on July 12 (Table 1; Figure 2). When comparisons are made on the same survey dates between years, the proportion of active nests was higher by $20 \%$ in 2002 (Figure 2).

Other bird species observed nesting among the western grebes included eared grebes, coots, ruddy ducks, common terns, Forster's terns, black terns, yellow-headed blackbirds, and red-winged blackbirds. Pied-billed grebes were commonly heard in the colony area, and were also likely nesting here. Interspecific brood parasitism by eared grebes occurred rarely occasionally in this western grebe colony: one nest was parasitized by one eared grebe egg on June 19, and one nest was parasitized by two eared grebe eggs on July 3. During the June 19 and July 12 surveys a single dead adult western grebe was observed. On June 26 two dead western grebe chicks were observed. Evidence of egg depredation within Lac Ste. Anne colony was moderate when compared to other colonies in the study area, with 10 depredated eggs observed (Appendix 3). A cottager living close to the colony heard coyotes on several occasions near the colony and possibly within the colony, suggesting that coyotes may depredate eggs from nests close to shore and possibly attack adults.

\subsubsection{Western Grebes on Wabamun Lake}

Western grebes on Wabamun Lake nested in the same location in 2002 as they did in 2001 (Hanus et al. $2002 \mathrm{a}, \mathrm{b})$. The total number of nests and estimated breeding adult population grew by nearly $35 \%$ from 560 nests and 1268 adults in 2001, to 755 nests and 1510 adults in 2002 (Table 1). Most of the nests at the July $4^{\text {th }}$ total nest count were in relatively good condition (Appendix 5), suggesting that the timing of the survey was good.

In 2002, the mean clutch size values steadily declined after the first survey on June 11 until June 26 (Figure 1). The maximum mean clutch size was $2.71 \mathrm{eggs} / \mathrm{nest}$, which was the lowest value among the western grebe colonies in the study area. After June 26 there was little change in the mean clutch size for active nests within the colony, but active nests only represented $6.4 \%$ of the nests surveyed. Two ground nest surveys were conducted in 2001: a partial survey on June 20 and a total nest count on June 27 (Hanus et al. 2001a,b). The mean clutch size observed in on June 20, 2001 was smaller by almost 0.4 eggs/nest when compared to the same day in 2002, but mean clutch sizes were identical between years on June 27 (Figure 1). Between June 11 and 19, 2002, there was a high proportion of active nests in the Wabamun Lake colony, after which there was a steady decline to the last survey on July 4 (Table 1; Figure 2). When comparing the proportion of active nests between years, there were 
almost $65 \%$ fewer active nests in 2001 on the June 20 survey date, and over $10 \%$ fewer on the June 27 survey date (Figure 2).

Other bird species observed nesting among the western grebes included red-necked grebes, coots, red-winged blackbirds, marsh wrens, and a goose. Pied-billed grebes were heard regularly in the area, and presumed to be nesting here. Seven western grebes were found dead on June 11, one of which likely died from fishing line wrapped around its leg and foot, and autopsies showed that the others died from mink predation. The evidence of egg depredation within Wabamun Lake colony was the highest in the study area, with 28 depredated eggs observed (Appendix 3). Dozens of depredated western grebe eggs were observed along the adjacent shoreline, and within the willow stand of the adjacent backshore. Crows were observed regularly depredating nests before, during and after ground nest surveys.

Table 1. Summary of western grebe data from 2002 surveys.

\begin{tabular}{|l|l|l|l|l|l|l|}
\hline Lake Name & $\begin{array}{l}\text { Survey } \\
\text { Date }\end{array}$ & $\begin{array}{l}\text { \# of } \\
\text { Adults }\end{array}$ & $\begin{array}{l}\text { \# of Nests } \\
\text { Surveyed }\end{array}$ & $\begin{array}{l}\text { Mean Clutch } \\
\text { Size (Eggs/Nest) }\end{array}$ & $\begin{array}{l}\text { Modal Clutch Size } \\
\text { (Eggs/Nest) }\end{array}$ & $\begin{array}{l}\text { \% Active } \\
\text { Nests }\end{array}$ \\
\hline Brock Lake & June 27 & 5 & 0 & - & - & - \\
\hline \hline Isle Lake** & June 10 & - & 27 & $2.95(\mathrm{n}=21)$ & $3(\mathrm{n}=21)$ & 77.8 \\
\hline Isle Lake* & June 19 & - & 59 & $2.74(\mathrm{n}=53)$ & $3(\mathrm{n}=53)$ & 89.8 \\
\hline Isle Lake** & June 26 & $124+$ & 62 & $2.27(\mathrm{n}=52)$ & $2(\mathrm{n}=52)$ & 83.9 \\
\hline Isle Lake* & July 3 & - & 40 & $1.97(\mathrm{n}=31)$ & $2(\mathrm{n}=31)$ & 77.5 \\
\hline $\begin{array}{l}\text { Lac La } \\
\text { Nonne** }\end{array}$ & June 20 & 20 & 0 & - & - & - \\
\hline Lac Ste. Anne* & June 11 & & 180 & $2.70(\mathrm{n}=169)$ & $3(\mathrm{n}=169)$ & 93.9 \\
\hline Lac Ste. Anne* & June 19 & & 268 & $2.84(\mathrm{n}=247)$ & $3(\mathrm{n}=247)$ & 92.2 \\
\hline Lac Ste. Anne* & June 26 & & 267 & $2.00(\mathrm{n}=176)$ & $2(\mathrm{n}=176)$ & 65.9 \\
\hline Lac Ste. Anne* & July 3 & & 258 & $1.59(\mathrm{n}=78)$ & $1(\mathrm{n}=78)$ & 30.2 \\
\hline Lac Ste. Anne** & July 12 & 802 & 401 & $1.74(\mathrm{n}=39)$ & $2(\mathrm{n}=39)$ & 9.7 \\
\hline \hline Sandy Lake*** & July 5 & $150 \pm$ & 0 & - & - & - \\
\hline \hline Wabamun Lake* & June 11 & & 326 & $2.71(\mathrm{n}=313)$ & $3(\mathrm{n}=313)$ & 96.0 \\
\hline Wabamun Lake* & June 19 & & 312 & $2.48(\mathrm{n}=299)$ & $3(\mathrm{n}=299)$ & 95.8 \\
\hline Wabamun Lake* & June 26 & & 257 & $1.81(\mathrm{n}=63)$ & $2(\mathrm{n}=63)$ & 24.5 \\
\hline $\begin{array}{l}\text { Wabamun } \\
\text { Lake** }\end{array}$ & July 4 & 1510 & 755 & $1.79(\mathrm{n}=48)$ & $2(\mathrm{n}=48)$ & 6.4 \\
\hline Total & & $\mathbf{2 6 1 1}$ & & & & \\
\hline
\end{tabular}

*Partial Ground Nest Survey

**Total Ground Nest Survey

***Meandering Shoreline Boat Survey 


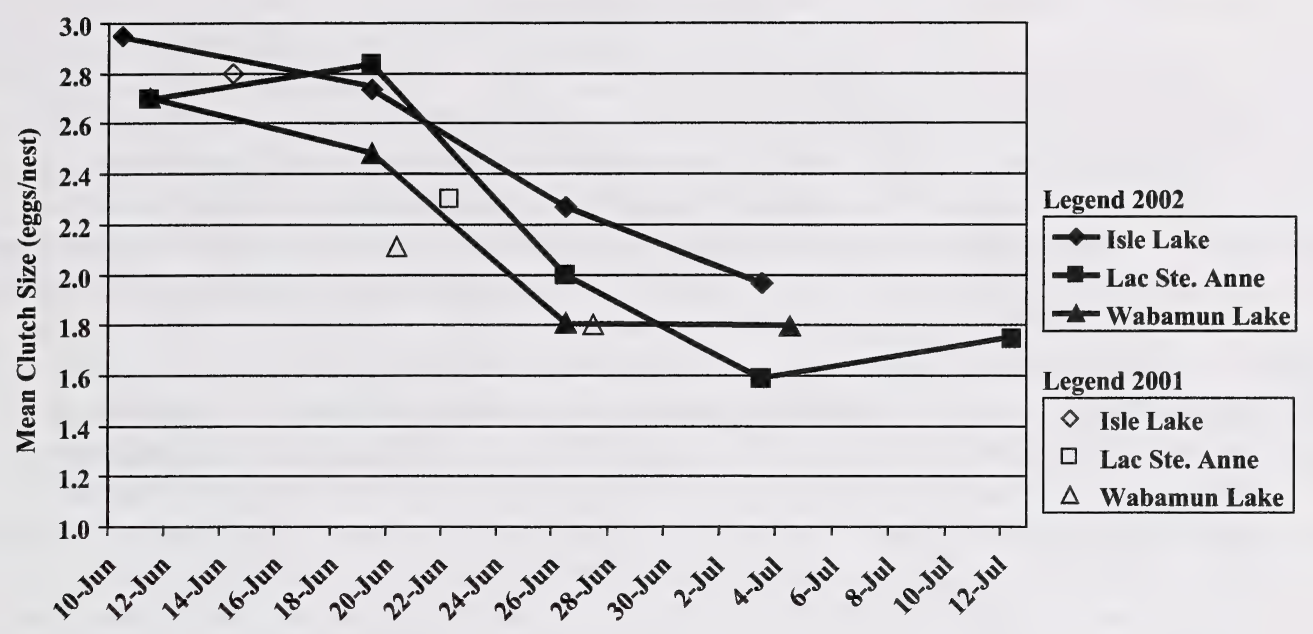

Date

Figure 1. Mean clutch sizes for western grebe colonies in the Stony Plain area, Alberta.

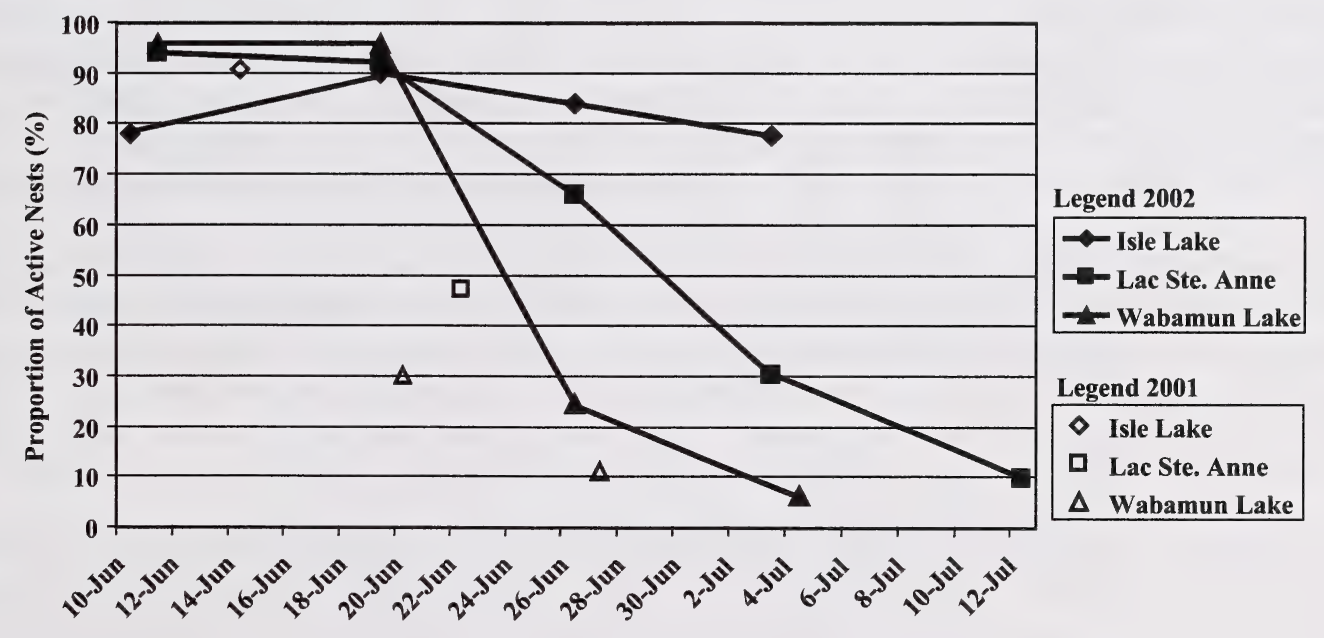

Date

Figure 2. Proportion of active nests for western grebe colonies in the Stony Plain area, Alberta. 


\subsection{Eared Grebes}

Surveys for eared grebes were conducted on 13 lakes, of which 10 lakes had eared grebe populations for a conservative overall population estimate of 8633 adults. Although our survey of the study area was not as thorough as in 2001, the 2002 overall population estimate was higher than the 2001 regional population estimate of 7632 adults. Eared grebe breeding colonies were observed on five of the 13 lakes surveyed in 2002. Eared grebe nests were counted on Isle Lake, Lac Ste. Anne, George Lake, and the unnamed lake south of Sandy Lake. A nest count of the Oldman Lake colony was not conducted due to logistical constraints. Clutch counts were conducted only on colonies on Isle Lake and Lac Ste. Anne. The largest eared grebe population was observed on George Lake, where over 2300 nests were counted and the adult population was estimated to exceed 5000 individuals. The number of eared grebe nests on George Lake was up 38\% from 2001, when 1666 nests were counted for a breeding population of approximately 3332 individuals. Of the remaining lakes with eared grebe populations, three had large populations over 500 individuals, four had medium sized populations between 100 and 500 individuals, and two lakes had small populations with fewer than 100 individuals (Table 2). Colonies located on Lac Ste. Anne and Isle Lake were located among western grebe nests within bulrush and cattail vegetation, respectively, whereas colonies at George Lake, Oldman Lake and the unnamed Lake south of Sandy Lake were in open water areas. On George Lake, several smaller 'satellite groups' of nests were located within patches of pond lilies along the northeast shore.

There was considerable variability of population sizes and nesting locations for eared grebes when compared to 2001 (Hanus et al. 2002a,b). Lakes that showed declines in eared grebe numbers since 2001 include Arthur Lake, Brock Lake, Lac Ste. Anne, and the unnamed lake south of Lac Ste. Anne. However, eared grebe numbers increased dramatically on George Lake, Isle Lake and Majeau Lake. Several nesting colonies were no longer active in 2002, which include colonies on Arthur Lake, Brock Lake, Lac Ste. Anne (west basin), and the unnamed colony south of Lac Ste. Anne. Three eared grebe colonies were located in similar locations in both survey years, and included colonies on George Lake, Isle Lake, and Oldman Lake. Of special interest, the nesting area on George Lake was much larger in 2002 than in 2001. In 2002, the nesting area was predominantly contained to the northwest corner of the lake, but in 2002 several new and small satellite groups established nests along portions of the entire north shore.

\subsubsection{Eared Grebes on Isle Lake}

The eared grebe population on Isle Lake nested with the western grebe colonies adjacent to two small islands (i.e. east and west island colonies), and were also considered as a single colony (see Section 4.1.1). Eared grebes were nesting at the east island colony location in both 2001 and 2002. However, in 2002 it appeared that nesting was delayed and there was low nesting success. The majority of eared grebes on Isle Lake nested at the west island colony location in 2002, but in 2001 (Hanus et al. $2002 a, b)$ there were no occurrences here.

Measures of reproductive success for eared grebes peaked later in the breeding season and appeared to have greater fluctuations within and between years, than for western grebes (Table 2; Figures 3 and 4). There were two distinctive peaks for mean clutch size values; the first peak occurred on June 19 (3.46 eggs/nest) and the second on July 3 (3.04 eggs/nest; Table 2; Figure 3 ). When comparing the same survey dates between years, values in 2002 were approximately 0.4 eggs/nest higher than in 
2001 (Figure 3). Between the two colonies on Isle Lake, there were considerable differences in terms of nest establishment and timing of peak egg production.

The proportion of active nests in the Isle Lake eared grebe colony remained high throughout the survey period, ranging from $65.7 \%$ to $92.4 \%$ (Table 2; Figure 4). Similar to mean clutch size trend, the proportion of active nests peaked twice during the 2002 surveys: the first on June 19, and the second on July 3 . The proportion of active nests in 2001 were over 10\% higher than in 2002 when comparing similar survey dates of June 17.

Some nesting habitat and behaviour differences were observed between nesting locations in 2002. At the east island colony location, dead bulrush vegetation from the previous year had been destroyed by snowmobile activity in the previous winter, thus the density of emergent vegetation was considerably less than at the west island colony location. Nesting was delayed by two weeks here compared to the west island location. When nesting did occur at the east island location, nests were often poorly constructed out of green algae vegetation, partly or entirely submerged, and many eggs were displaced from nests. Adults re-nested multiple times at the east island colony location as a result of several wind storms that had occurred.

A total count of nests was conducted on July 3,2002. The east island colony had a maximum of 303 nests (Table 2) within an area of bulrush approximately $100 \mathrm{~m}$ long and $40 \mathrm{~m}$ wide. A total count was not conducted for the west island colony due to logistical constraints but approximately three quarters of the colony was counted, with an estimate of 383 nests. Therefore, the total number of nests in the west island colony was projected to be approximately 511 . These nests were concentrated within a small area approximately $100 \mathrm{~m}$ long and $30 \mathrm{~m}$ wide, where cattails were the dominant vegetation present, followed by bulrush. This was the highest density of nests observed in two years of surveys. By combining the estimated number of nests from these two counts, the total nest count for Isle Lake is 814 nests with an estimated breeding population of 1628 individuals. As a result, the total number of nests and estimated breeding population more than doubled in 2002.

An unprecedented number of dead eared grebes were observed in the west island colony location on June 19. A total of 41 were found dead, 11 with obvious predation wounds possibly caused by mink. A total of 17 depredated eared grebe eggs were observed in this colony, all of which occurred in the west island colony location (Appendix 4). Similar to the observations from 2001, eared grebes eggs were found in western grebe nests (see Section 4.1.1). Clutches were generally higher in the central area of the west island colony location, often ranging from six to 13 eggs per nest. As well, there were signs of egg dumping where dozens of abandoned eggs were piled into deteriorated nests and found sunken on the lake bottom. The Isle Lake eared grebes also expressed these nesting behaviours in 2001, but only in the east island colony location.

\subsubsection{Eared Grebes on Lac Ste. Anne}

Eared grebes formed colonies on Lac Ste. Anne in both 2001 and 2002, but are very distinct from one another. In 2001, they nested in an open water area in the shallow and secluded west basin, whereas in 2002 they nested among western grebes in the bulrush area of the highly developed east basin. Comparisons in reproductive measures between years are not considered appropriate due to habitat differences, which would likely influence nesting success and behaviour. Also, relatively large distant between nesting sites (i.e. $11.5 \mathrm{~km}$ ) makes it more likely that different individuals comprised the colonies between years. On July 12, 2002 a total of 87 nests were counted for a breeding population 
of approximately 174 individuals. Colony establishment was relatively late, as nests were not observed until June 19. The trend for egg production differed from the Isle Lake colony, as shown in Table 2 and Figure 3. The maximum clutch size of 2.55 eggs/nest occurred on July 3, 2002, which occurred two weeks after the peak observed for the Isle Lake population, and clutches were on average 0.91 eggs/nest smaller (Table2; Figure 3 ).

The proportion of active eared grebe nests for the Lac Ste. Anne colony remained high throughout the survey period, ranging from $100 \%$ to $81.6 \%$ (Table 2; Figure 4). Similar to the Isle Lake eared grebe colony, there was a marked dip in the proportion of active nests on June 26 , followed by a subsequent increase. A total of 8 depredated eared grebe eggs were observed throughout the survey period (Appendix 4). No dead eared grebes or signs of egg dumping were observed in the Lac St. Anne colony, and rarely did eared grebes parasitize western grebe nests with their eggs (see section 4.1.2).

Table 2. Summary of eared grebe data from 2002 surveys.

\begin{tabular}{|c|c|c|c|c|c|c|}
\hline Lake Name & $\begin{array}{c}\text { Survey } \\
\text { Date }\end{array}$ & $\begin{array}{c}\text { \# of } \\
\text { Adults }\end{array}$ & $\begin{array}{l}\text { \# of Nests } \\
\text { Surveyed }\end{array}$ & $\begin{array}{l}\text { Mean Clutch Size } \\
\text { (Eggs/Nest) }\end{array}$ & $\begin{array}{l}\text { Modal Clutch Size } \\
\text { (Eggs/Nest) }\end{array}$ & $\begin{array}{l}\text { \% Active } \\
\text { Nests }\end{array}$ \\
\hline Arthur Lake & July2 & 2 & 0 & - & - & - \\
\hline Big Lake & June 12 & $150+$ & 0 & - & - & - \\
\hline Brock Lake & June 27 & $183+$ & 0 & - & - & - \\
\hline George Lake & June 28 & $5000+$ & $2300+$ & - & - & - \\
\hline Isle Lake (EIC)* & June 10 & & 17 & 3.00 & 3 & 5.9 \\
\hline Isle Lake (WIC)** & June 10 & & 193 & 1.84 & 1 & 71.0 \\
\hline Isle Lake (Overall)*** & June 10 & & 210 & 1.85 & 1 & 65.7 \\
\hline Isle Lake (EIC)* & June 19 & & 22 & 1.79 & 1 & 86.4 \\
\hline Isle Lake (WIC) ${ }^{* *}$ & June 19 & & 359 & 3.56 & 3 & 92.8 \\
\hline Isle Lake (Overall)*** & June 19 & & 381 & 3.46 & 3 & 92.4 \\
\hline Isle Lake (EIC)* & June 26 & & 249 & 1.64 & 1 & 65.1 \\
\hline Isle Lake (WIC)** & June 26 & & 257 & 3.43 & 3 & 96.9 \\
\hline Isle Lake (Overall)*** & June 26 & & 506 & 2.69 & 1 & 81.2 \\
\hline Isle Lake (EIC)* & July 3 & & 303 & 2.36 & 3 & 81.2 \\
\hline Isle Lake (WIC)** & July 3 & & 383 & 3.50 & 3 & 95.8 \\
\hline Isle Lake (Overall)*** & July 3 & $1628^{\Psi}$ & 686 & 3.04 & 3 & 89.4 \\
\hline Lac Ste. Anne & June 19 & & 14 & 1.64 & 1 & 100 \\
\hline Lac Ste. Anne & June 26 & & 38 & 2.42 & 2 & 81.6 \\
\hline Lac Ste. Anne & July 3 & & 42 & 2.55 & 2 & 95.2 \\
\hline Lac Ste. Anne & July 12 & 174 & 87 & 2.44 & 2 & 82.8 \\
\hline Majeau Lake & June 25 & 800 & 0 & - & - & - \\
\hline Oldman Lake & June 25 & $349+{ }^{4 \Psi}$ & 0 & - & - & - \\
\hline Sandy Lake & July 5 & $55+$ & 0 & - & - & - \\
\hline $\begin{array}{l}\text { Unnamed Lake South of } \\
\text { Sandy Lake }\end{array}$ & July 5 & 292 & 146 & - & - & - \\
\hline Total: & & $8633^{\Psi \Psi \Psi}$ & & & & \\
\hline
\end{tabular}

*Isle Lake (EIC) represents the eared grebe colony in the East Island Colony Location.

**Isle Lake (WIC) represents the eared grebe colony in the West Island Colony Location.

***Isle Lake (Overall) represents the combined eared grebe colonies in the East and West Island Colony Locations.

${ }^{\Psi}$ Adult population assumptions and calculation:

Assumed a total nest count for EIC (303 nests)

Assumed $3 / 4$ of WIC was surveyed ( 383 nests counted so total count extrapolated to be 511 nests)

Calculation: ( 303 nests (EIC) +511 nests (WIC) ) $2=814$ nests $\times 2=1628$ breeding adults on Isle Lake.

${ }^{4 \Psi}$ This estimate represents the actual number of eared grebes counted, which is likely an underestimate of the actual population size by two to three times.

${ }^{\Psi \Psi \Psi}$ This total is a conservative estimate for the 10 lakes surveyed, and underestimates the regional population. 


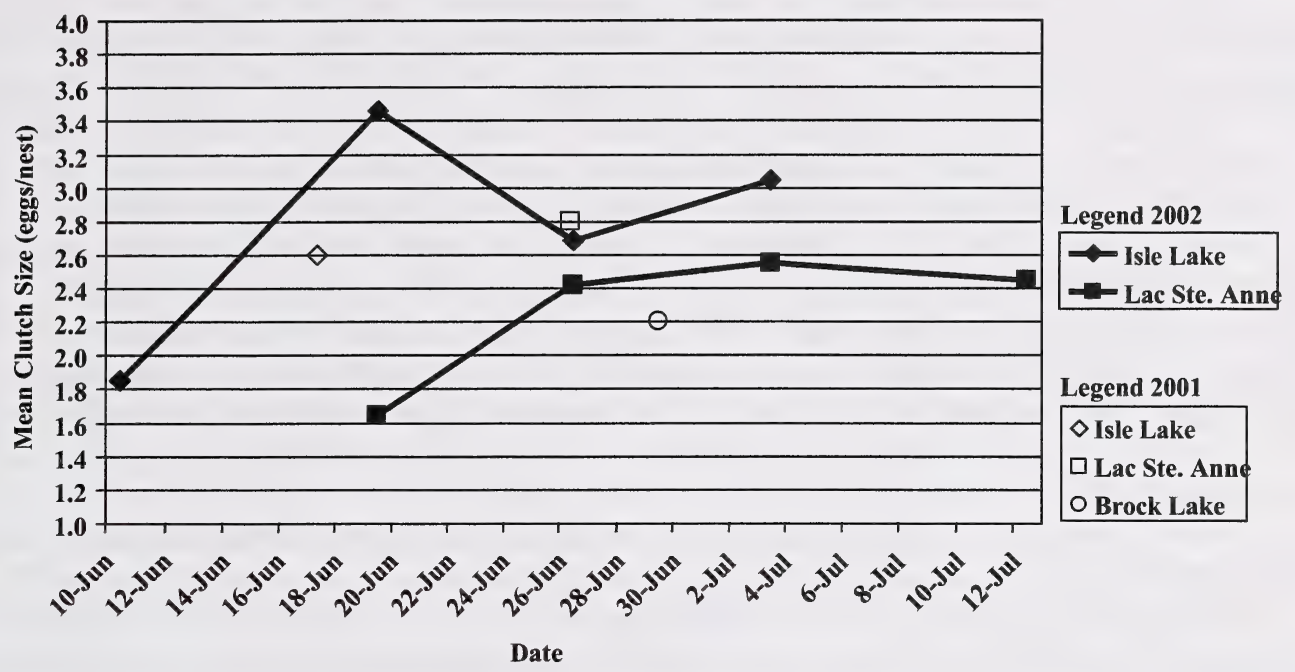

Figure 3. Mean clutch sizes for eared grebe colonies in the Stony Plain area, Alberta.

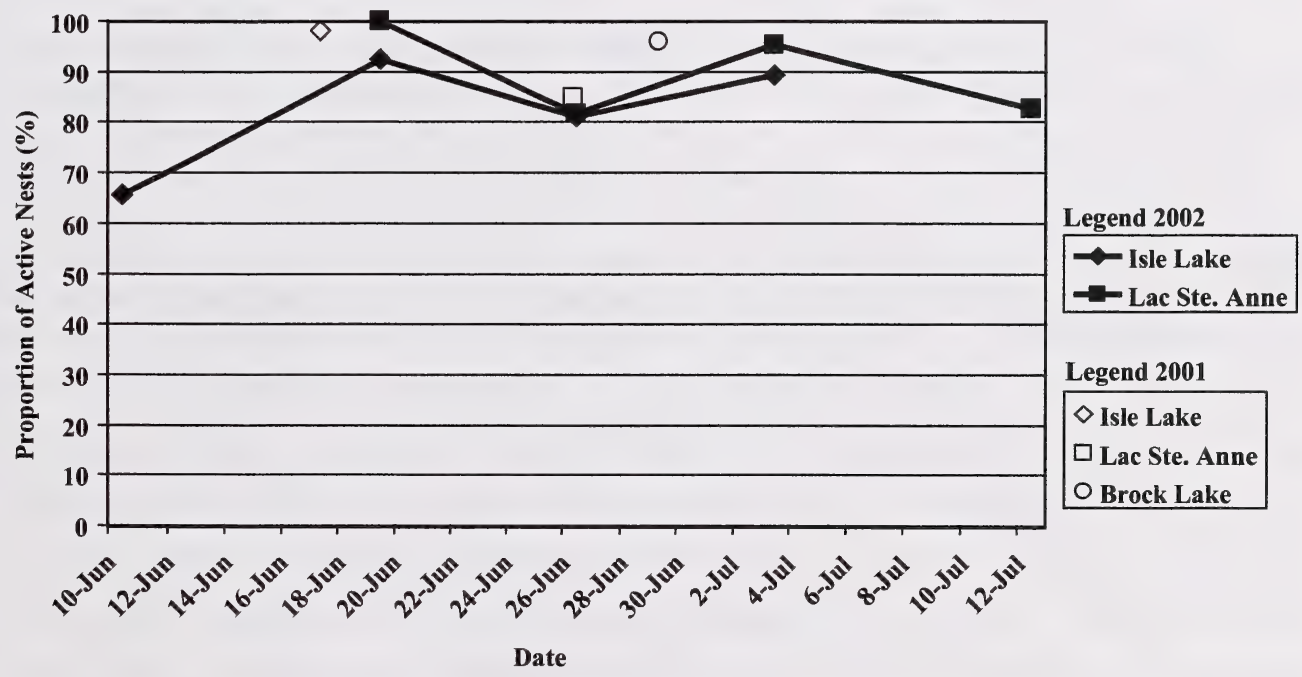

Figure 4. Proportion of active nests for eared grebe colonies in the Stony Plain area, Alberta. 


\subsection{Implementation of 2001 Management Implications}

Based on the management implications outlined in Hanus et al. (2002a) we focussed our efforts on continued monitoring of primary colonies using consistent techniques, establishment of public awareness signs, and public education via presentations and newsletter articles. We established protective notations (i.e. PNTs) for western grebe colonies where they did not already exist. We did not establish PNTs specifically for eared grebe colonies, due to the variability in nesting locations. If it becomes apparent that some eared grebe colonies occur in the same location from year to year, establishment of PNTs would be worthwhile. To promote public awareness of western grebes and shoreline habitat conservation, we developed two signs we term as the 'western grebe conservation' sign (Appendix 6), and the 'shoreline habitat conservation' sign (Appendix 7). A total of 11 signs were placed at the primary boat launches of five lakes within the study area (Appendix 8). Further details of the signs are provided in Appendix 9. Wherever the opportunity presented itself, presentations about colonial grebes and shoreline habitat conservation where given (Appendix 10). Articles were written for the Killowatt Connection, which is disseminated by TransAlta Utilities throughout the study area, and the Alberta Wildlifer, which has provincial dissemination to members of the Alberta Chapter of the Wildlife Society. Progress was also made expanding the monitoring efforts outside of the Stony Plain study area. The Lesser Slave Lake Bird Observatory implemented a western grebe monitoring program based on the protocols outlined in Hanus et al. (2002a) and in this report. A summary of the findings from the 2002 field season at Lesser Slave Lake is provided in Eadie (2002).

\subsection{DISCUSSION}

\section{$\underline{5.1 \text { Western Grebes }}$}

Based on successful surveys in 2002 we were able to update the status of known western grebe populations in the Stony Plain study area. Populations and nesting colonies identified in 2001 were still present in 2002. We estimated the regional population of western grebes to be slightly higher in 2002 , but this minor change at the regional scale is likely within the natural range of variation. In addition, a certain amount of variation is expected due to imprecision associated with survey techniques. The Stony Plain study area continues to support populations that are of regional and national significance. Poston et al. (1990) developed a ranking classification for migratory birds inhabiting the Canadian Prairie Provinces, and stated that western grebe colonies with over 500 nests or breeding pairs are considered nationally significant, and colonies with a range of 100 to 500 nests or breeding pairs are considered regionally significant. As such, the Wabamun Lake colony easily surpassed the criterion that ranks it as nationally significant for the second year, and the Lac Ste. Anne colony fell from being nationally significant in 2001 to regionally significant in 2002. From a conservation and management perspective, it is imperative that these populations are sustained over the long-term.

We determined that the peak nesting period for western grebes occurred between June 10 and June 19, 2002. Ground nest surveys in the Wabamun Lake and Lac Ste. Anne colonies occurred after these dates in 2001, suggesting that reproductive measures did not reflect the true maximums with assumption that timing of nesting was similar between years. The peak of the nesting season in the Stony Plain study area differs from a western grebe study on Cold Lake, Alberta (Kristensen and 
Nordstrom 1979), which reported the peak to occur between mid and late June. This difference may be attributed to geographical differences between study areas, with the Kristensen and Nordstrom (1979) study site being approximately $300 \mathrm{~km}$ northeast of the Stony Plain study area. It is also likely that some seasonal factors, such as water level and spring ice break-up, influence timing of nesting.

The results from our 2002 surveys suggest that egg production within our study area is within the range of results reported in other studies conducted in Canada and the northwestern United States. The maximum mean clutch size ranged from 2.71 eggs/nest on Wabamun Lake to 2.95 eggs/nest on Isle Lake in 2002, while in the literature values ranged from 2.6 eggs/nest to 3.7 eggs/nest (Forbes 1988, Kristensen and Nordstrom 1979, Lindvall and Low 1982, Riske 1976). Modal clutch sizes for colonies in the study area were also similar to those reported in the literature. Each colony reported a maximum modal clutch size of three eggs per nest, while other studies reported values ranging from three to four eggs per nest (Herman et al. 1969, Nero 1959, and Riske 1976).

Clarification is required for the unexpected increase and plateau of the mean clutch sizes near the end of the survey period for Lac Ste. Anne and Wabamun Lake colonies, respectively (Figure 1). These values were calculated from active nests only, and at the time of the surveys the number of active nests was very small compared to the total number of nests counted. Nests used for these calculations may represent either abandoned nests with sterile eggs, or active nests established late in the season thereby skewing the egg production measurement. Nevertheless, the overall impact of these potential biases is likely small.

The threats of human impacts on and around the lakes colonized by western grebes continue to be apparent within the study area. As an example, a housing development is proposed on the land directly adjacent to the western grebe colony on Lac Ste Anne. This would negatively impact nesting western grebes by increasing human presence in the area, powerboat disturbances, and increase the presence of corvids and dogs, while reducing, fragmenting and marginalizing the nesting habitat. Based on complete shoreline surveys for emergent vegetation habitat in 2002, the current location of the colony is within the largest and most intact section of bulrush habitat found on the lake. It appears that western grebes have already moved away from areas of high disturbance to this more secluded location (Hanus et al. 2002a, Purdy et al. 1983), and if other viable habitat is not available for another relocation then the likelihood that western grebes will continue colonizing Lac Ste. Anne over the long-term is greatly reduced. This is a classic example of the pressures western grebe colonies are facing within the study area, and if left unmitigated, the regional population of colonial grebes will suffer.

\subsubsection{Western Grebes on Isle Lake}

Of the colonies surveyed using the ground nest survey technique, Isle Lake had the smallest population. The number of western grebes declined slightly from 2001 (Hanus et al. 2002a), but this change is likely within the natural range of variation, and within the expected variance associated with the surveying technique. Mean clutch size values from similar survey dates in 2001 and 2002 differed only slightly, suggesting very little variation in egg production between years. Since we determined the peak nesting season for western grebes occurred between June 10 and June 19, the June 14 survey data in 2001 was a relatively close estimate of the maximum mean clutch size assuming similar timing between years. 
In both years of this project, the Isle Lake western grebe colony had higher mean clutch sizes than both the Wabamun Lake and Lac Ste. Anne colonies. Unlike the other colonies, very little egg depredation has occurred in the Isle Lake colony and no dead adults have been found. The location of the nesting site away from the shore is likely beneficial to western grebes in this case, which offers more seclusion from land-based predators, such as coyotes and even corvids, and results in higher reproductive success than at shoreline locations. However, there are trade-offs to colonizing these small islands, namely that they are more exposed to wind, wave, and human disturbance than a typical shoreline colony would be. The impacts of these disturbances are likely dependent on the density of bulrush habitat, which buffers the impacts of these disturbances but varies in density from year to year.

There were some interesting changes in habitat use among western grebes nesting on Isle Lake. Early in the season, it appeared that western grebes were establishing their colonies within the east and west island colonies as they did in 2001. However, there were two underlying circumstances in 2002 that may have caused them to abandon the east island colony location and shift toward the west side of the west island colony location. First, nesting habitat quality was significantly reduced at the east island colony location because snowmobile activity destroyed the dead bulrush vegetation during the 2001/2002 winter season. As a result, there was little material available for nest construction before new bulrush emerged, and there was less protection from incoming waves than in previous years. Second, the number of eared grebes inhabiting Isle Lake greatly increased in 2002, and many of them established nests in a very dense concentration where western grebes nested the previous year. Egg parasitism by eared grebes and possible harassment may have caused western grebes to abandon their nests and relocate to the more secluded part of the island. These potential causes of delayed nesting or re-nesting occurrences may explain why the proportion of active nests was slightly lower in 2002 than in 2001.

\subsubsection{Western Grebes on Lac Ste. Anne}

Western grebes on Lac Ste. Anne nested in the same location as the previous year, but the population size decreased considerably in 2002 with no apparent change in nesting habitat quality. It is unclear whether this indicates a declining population trend, if some birds are nesting in another location on Lac Ste. Anne, or if some western grebes are nesting on a different lake altogether. A meandering shoreline survey of the high quality nesting habitat yielded no evidence that additional western grebe colonies were established on Lac Ste. Anne. It is possible that some breeding pairs may have nested on Wabamun Lake instead of Lac Ste. Anne, since the population change between these two lakes is nearly inversely proportional. Further years of data are required to determine if this change is within natural variation or indicative of a downward trend.

Reproductive measures for the Lac Ste. Anne colony are within the range presented in the literature, but lower when compared to previous studies conducted on Lac Ste. Anne. The maximum mean clutch size in 2002 (i.e. 2.84 eggs/nest) is less than the 3.0 eggs/nest recorded during a previous study on Lac Ste. Anne (Riske 1976). The mean clutch size and proportion of active nests on the same survey date is lower in 2002 than 2001. It is unclear whether these differences represent poorer reproductive output in 2002 , natural variation between years, or precision errors caused by extrapolating data between survey dates in 2002. 


\subsubsection{Western Grebes on Wabamun Lake}

In 2002, the western grebe population on Wabamun Lake increased dramatically. Interestingly, this increase is approximately proportional to the decline observed among the population at Lac Ste. Anne. As mentioned earlier, this may be indicative that some birds shift their nesting location from year to year.

Our results suggest that the western grebes on Wabamun Lake are producing eggs within the lower end of the range presented in the literature, and their hatching success appears to be significantly lower than expected. Our results show that the mean clutch size and proportion of active nests peaked early in the nesting season, but were followed by a steep decline. As well, these values were also lower compared to the other colonies in the study area throughout much of the nesting season. Extremely high rates of egg depredation by crows appear to be the primary reason for these observations. Although egg depredation is a naturally occurring threat to western grebes, the proximity of the colony to urban, industrial and cottage developments likely has elevated the crow population from natural levels. It appears plausible that the current rate of offspring recruitment is not sufficient to replace the annual adult mortality. If true, our results suggest that the long-term viability of the Wabamun Lake colony is in jeopardy and needs to be addressed, especially considering the national significance of this colony. Mitigative actions are being explored to help ensure that Wabamun Lake does not become a population sink.

\subsubsection{Western Grebes on Sandy Lake}

One new western grebe population was identified on Sandy Lake. There are no known records of western grebes inhabiting Sandy Lake in the past (Hanus 2002). Discussions with a resident of the Sandy Lake area (Pers. Com. T. Trusz 2002) revealed that western grebes began to inhabit the lake in the summer of 1999. Small numbers were observed initially, but the population has grown steadily each year since. Although our survey did not confirm the location of a nesting colony, the majority of western grebes were observed in the southeast corner of the lake among the bulrush. The recent colonization by western grebes on Sandy Lake may be due to three primary factors. First, there has been a considerable decline in the presence of recreational boaters on Sandy Lake over the past few years, likely due to the sport fisheries collapse and the water table decline. Second, grebe prey species may now be relatively abundant with the decline in top predator fish, such as mature northern pike, younger cohorts of these species and other small fish species may be more abundant. Finally, Sandy Lake offers excellent nesting habitat for western grebes along the entire east shore. This area is adjacent to an Indian Reserve, and as such, the bulrush habitat and backshore vegetation is largely undisturbed. Sandy Lake is an interesting case study, which indicates that the presence of available nesting habitat, reduced motorized boating disturbance, and good availability of prey species may be key to colony establishment.

\subsubsection{Western Grebes on Lac La Nonne}

The small western grebe population on Lac La Nonne may be reflective of the impacts caused by humans, such as boating disturbances, fishing pressures and intensive shoreline development. Our surveys in 2002 suggest that the population of western grebes continue to be small (i.e. approximately 20 individuals). Although viable bulrush nesting habitat is present, intensive reconnaissance of these areas yielded no evidence that western grebes were nesting on Lac La Nonne. Special conservation 
and management efforts may be required to sustain the Lac La Nonne population of western grebes over the long-term and encourage nesting.

\section{$\underline{5.2 \text { Eared Grebes }}$}

The estimated number of eared grebes increased by over $10 \%$ from 2001 to 2002 , although the number of lakes surveyed was greatly reduced between years. The influx of eared grebes, especially on George Lake and Isle Lake, may be the result of drought conditions throughout much of southern and central Alberta, which likely reduced the number of suitable waterbodies for nesting. When comparisons in population size are made on a lake-by-lake basis, it is apparent that eared grebes rely on a network of waterbodies to sustain their regional population over the long-term. Hanus et al. (2002a) reported considerable changes in eared grebe population sizes and colony locations within the study area when compared to historic surveys conducted by Purdy et al. (1983). These findings were expected since it is fairly characteristic for eared grebes to shift nesting locations (O'Donnel and Fjeldsa 1997), especially given that approximately 20 years had elapsed between these two studies. Yet similar results were observed between 2001 and 2002 without any noticeable differences in human disturbance. This shows very clearly that eared grebes are quite dynamic when it comes to selecting lakes on which to forage and nest. These changes may be partly due to seasonal changes in water level and habitat quality, or there may be a high availability of suitable waterbodies within the study area thereby reducing fidelity to individual sites between years.

Several important breeding populations of eared grebes are present in the study area. Poston et al. (1990) define nationally significant colonies as those over 800 nests, regionally significant colonies as having 300 to 800 nests, and locally significant colonies as having fewer than 300 nests. For the second year in a row, the George Lake colony surpassed the minimum requirement for nationally significant colonies by a considerable margin: in 2002 it was by 2.9 times. This lake provides ideal nesting habitat for eared grebes because it is relatively shallow, submergent vegetation is highly abundant and readily available for nest construction, there is minimal human presence on and around the lake, a powerboat restriction is in place, and the shorelines are relatively intact. With the large influx of eared grebes observed on Isle Lake, this population also ranked as nationally significant. Of all lakes inhabited by eared grebes within the study area, the characteristics of this lake represents the greatest departure from more typical eared grebe breeding lakes, such as George Lake, due to its large size and high level of development. Oldman Lake is very difficult to survey from the ground, but there appeared to be a colony of considerable size, likely retaining its status of regionally significant. A nesting colony was not observed on Majeau Lake, but enough birds were present to rank this population as regionally important.

Powerboat disturbance and high human presence have an important role in habitat use by eared grebes. In 2002, seven of the 10 waterbodies with populations and/or colonies of eared grebes were not highly developed and had powerboat restrictions, which is similar to the findings reported in Hanus et al. (2002a). It appears that eared grebes may prefer these secluded and shallow lakes, especially when nesting in open water areas. These are consistent with the findings of Boe (1992), who determined that eared grebes preferred shallow waterbodies $\leq 3 \mathrm{~m}$ deep, wetlands without designated public access and little or no fishing or motorboating, shorelines that were partially treed, and abundant submergent vegetation. Boe (1992) did not observe eared grebes on wetlands with buildings along the shoreline, suggesting avoidance behaviour. 
Eared grebes continued to express healthy reproductive output within the study area. The peak mean clutch size for the Isle Lake population was 3.46 eggs/nest on June 19, 2002, while on Lac Ste. Anne the eared grebes had a peak mean clutch size of 2.55 on July 3,2002. These values are within the natural range of variation (i.e. 2.2 eggs/nest to 3.7 eggs/nest) when compared to other studies in Alberta (Riske 1976), British Columbia (Forbes 1985, McAllister 1958), and the western United States (Gould 1974). As well, the proportion of active nests throughout the survey period remained over $81 \%$, suggesting that the majority of egg hatching and nest abandonment occurred after July 3 for the Isle Lake colony and July 12 for Lac Ste. Anne colony. As was the case in 2001, the rate of nest depredation was very low, suggesting that egg depredation is not currently a major threat to eared grebes.

It appears that eared grebes begin nesting later in the season when compared to western grebes, and subsequently the timing of the maximum egg production also occurs later in the season. We observed the peak nesting period to occur between June 19 and July 3 . These findings are consistent with those produced from 2001 surveys (Hanus et al. 2002a,b).

\subsubsection{Eared Grebes on Isle Lake}

Based on ground nest surveys conducted in the Isle Lake eared grebe colony, it is apparent that differences in nesting habitat quality influenced timing of nest establishment, egg production, and reproductive success. Although the two nesting sites (i.e. east and west island colony location) are typically similar, habitat quality at the east island colony location was reduced in 2002 (see Section 5.1.1), and as a result, nesting was greatly delayed, nests were poorly constructed, and nesting success was negatively impacted. Eared grebes at this location may have been young and inexperienced nest builders and/or latecomers, and as such were out-competed from the higher quality nesting area in the west island colony location

These differences among nesting locations help explain the fluctuations in the overall mean clutch sizes (Figure 3 ) and proportion of active nests (Figure 4) during the course of the survey period. The decrease in values for mean clutch size and proportion of active nests mid-way through the survey period (i.e. June 26), was largely attributed to the influx of recently built nests observed in the east island colony location that had incomplete clutches (Table 2). By the next survey (July 3), these nests had more complete clutches (Table 2) and the proportion of active nests increased.

Eared grebes of Isle Lake also exhibited evidence of 'egg dumping' and inter- and intraspecific nest parasitism both in 2001 and 2002. This nesting behaviour is not uncommon for eared grebes (Hill et al. 1997, Lyon and Everding 1996, Gollop 1958, Bent 1963). For example, Lyon and Everding (1996) determined that $38 \%$ of 47 nests in two colonies experienced brood parasitism. The high density of nests on Isle Lake likely explains these behaviours. Hill et al. (1997) observed that intraspecific brood parasitism, egg loss due to conspecific interference, aggression rates, and time spent in aggressive activities were higher in high-density colonies than in the low-density colony. Although Isle Lake is large, alternative nesting sites are likely not available, resulting in the overpopulation of suitable sites. 
Differences in the timing of colony establishment and egg production highlight some of the dynamics for eared grebes within a lake between years, and between lakes in the same year. Eared grebes established their colony on Lac Ste. Anne relatively late in the season (i.e. June 19) when compared to the Isle Lake colony. When comparing clutch sizes between the two lakes, values from Lac Ste. Anne were smaller throughout the nesting season and also peaked later in the season. These differences reinforce the need to survey multiple times throughout the breeding season.

The trend of egg production in the Lac Ste. Anne colony appears to be typical of a colony during colony establishment and peak nesting phases of development (Figure 3). The trend for the proportion of active nests was more irregular and is likely reflective of surveying biases. The peak for the proportion of active nests occurred on the first survey date of June 19. However, this is somewhat misleading since the colony only recently became established and the sample size was relatively low. There was a decrease in the proportion of active nests at the June 26 survey date, and subsequent increase. This fluctuation was likely due to the influx of many new nests being established at this time, thus many breeding pairs were still in the early stages of nest building and egg production. As a result, the true peak of the nesting season for this colony occurred by July 3, 2002.

\subsection{MANAGEMENT IMPLICATIONS AND FUTURE DIRECTION}

The Stony Plain study area supports sizable populations of both western and eared grebes, due in part to the large number of medium to large-sized waterbodies. Short-term results of this monitoring project indicate that western grebes have relatively high fidelity to existing nesting sites. Western grebes rely on the largest lakes in the study area to support their regional populations, so they are limited to where they can nest. These lakes are also some of the most developed and recreated lakes within the study area. Public education should continue to focus on local groups, landowners, and land managers at these lakes. Shoreline habitat restoration should also become a priority for this project in the future. Concern for western grebe status over the long-term continues to exist, due to the poor nesting success of the Wabamun Lake colony, and encroachment of human disturbances on existing colonies and potential alternative nesting sites. The Sandy Lake population requires additional baseline surveys in 2003 . The colony location should be identified early in the breeding season, and regular ground nest surveys should be incorporated into the schedule of surveys within the study area. The success of the western grebe surveys conducted by the Lesser Slave Bird Observatory highlights the eagerness of other organisations to monitor western grebe populations. Now that survey techniques have been refined, future efforts should be dedicated to establishing monitoring programs in other regions of the province.

Eared grebes appear to be variable in terms of their population dynamics and nesting location fidelity. It is apparent that eared grebes rely on a network of waterbodies to sustain their regional population over the long-term, so ensuring that some of these waterbodies do not become developed is critical. As a minimum, continued monitoring of the key populations in the study area is recommended in order to assess population trends, supplement the existing database, and further understand the dynamics of site fidelity in the study area. Wherever possible, smaller populations of eared grebes should be surveyed, and new sites should be reconnoitred in order to determine what 'network of waterbodies' are used by eared grebes over time. 


\subsection{LITERATURE CITED}

Alberta Environmental Protection. 1994. Natural Regions of Alberta: Summary. Alberta Environmental Protection. Edmonton, AB. 18 pp.

Alberta Sustainable Resource Development. 2000. The general status of Alberta wild species, 2000. Alberta Environment/Alberta Sustainable Resource Development. Edmonton, AB. 46 pp.

Baicich, P. J. and C. J. O. Harrison. 1997. A guide to the nests, eggs, and nestlings of North American Birds. Second edition. Academic Press. San Diego, CA, USA. 347 pp.

Boe, J. S. 1992. Wetland selection by eared grebes, Podiceps nigricollis, in Minnesota. Canadian Field-Naturalist 106:480-488.

Eadie, G. 2002. 2002 Lesser Slave Lake western grebe survey. Lesser Slave Lake Bird Observatory. Slave Lake, AB. 28pp.

Forbes, S. 1988. Western grebe nesting in British Columbia. The Murrelet 69(1):28-33.

Gollop, J. B. 1958. Do Eared Grebes have dump nests? Blue Jay 16:151.

Gould, G. E. 1974. Breeding success of piscivorous birds at Eagle Lake, California, M.Sc. thesis, Humbolt State University, Arcata, California.

Hanus, S. 2002. Western (Aechmophorus occidentalis) and Eared (Podiceps nigricollis) Grebe Data of Alberta. Alberta Sustainable Resource Development, Fish and Wildlife Division, Edmonton, $\mathrm{AB}$.

Hanus, S., H. Wollis, and L. Wilkinson. 2002a. Western (Aechmophorus occidentalis) and Eared (Podiceps nigricollis) Grebes of Central Alberta: Inventory, Survey Techniques, and Management Concerns. Alberta Sustainable Resource Development, Fish and Wildlife Division, Species at Risk Report No. 41. Edmonton, AB. 45pp. http://www3.gov.ab.ca/srd/fw/riskspecies/

Hanus, S., H. Wollis, and L. Wilkinson. 2002b. Supplemental Information. Western (Aechmophorus occidentalis) and Eared (Podiceps nigricollis) Grebes of Central Alberta: Inventory, Survey Techniques, and Management Concerns. Alberta Sustainable Resource Development, Fish and Wildlife Division. Internal Report. 44pp.

Herman S. G., R. L. Garrett, and R. L. Rudd. 1969. Pesticides and the western grebe: A study of pesticide survival and trophic concentration at Clear Lake, Lake County, California. pp. 24-55. In M. W. Miller and G. G. Berg (eds.). 1969. Chemical Fallout: Current Research. Charles C. Thomas, Springfield, IL.

Hill, W. L., K. J. Jones, C. L. Hardenbergh, and M. Browne. 1997. Nest distance mediates the costs of coloniality in Eared Grebes. Colonial Waterbirds 20:470-477. 
Kristensen, J., and W. R. Nordstrom. 1979. Western grebe colony, Cold Lake. Provincial parks Division, Alberta Recreation, Parks and Wildlife. 47 pp.

Lindvall, M. L., and J. B. Low. 1982. Nesting ecology and production of western grebes at Bear River Migratory Bird Refuge, Utah. Condor 84:66-70.

McAllister, N. 1958. Courtship, hostile behaviour, nest establishment and egg laying in the eared grebe (Podiceps caspicus). Auk 75:290-311.

Nero, R. W. 1959. Western Grebe Colony. Nat. Hist. 68:291-295.

O'Donnel, C. and J. Fjeldsa (compilers).1997. Grebes - Status survey and conservation action plan. IUCN/SSC Grebe Specialist Group. IUCN. Gland, Switzerland and Cambridge, UK. vii + 59 $\mathrm{pp}$.

Poston, B., D. M. Ealey, P. S. Taylor, and G. B. McKeating. 1990. Priority migratory bird habitats of Canada's prairie provinces. Minister of Supply and Services Canada. Edmonton, AB. 107 pp.

Purdy, R.O., D.C. Parkyn, and J.D. Folinsbee. 1983. Wildlife surveys of selected Edmonton area lakes June-July 1982. Unpub. Rep. Alberta Energy and Natural Resources, Fish and Wildlife Division. 139 pp.

Riske, M. E. 1976. Environmental and human impacts upon grebes breeding in central Alberta. PhD. Thesis, University of Calgary. Calgary, AB. 482 pp. 
8.0 APPENDICES 
Appendix 1 Map of Alberta, the Stony Plain study area and distribution of grebe colonies

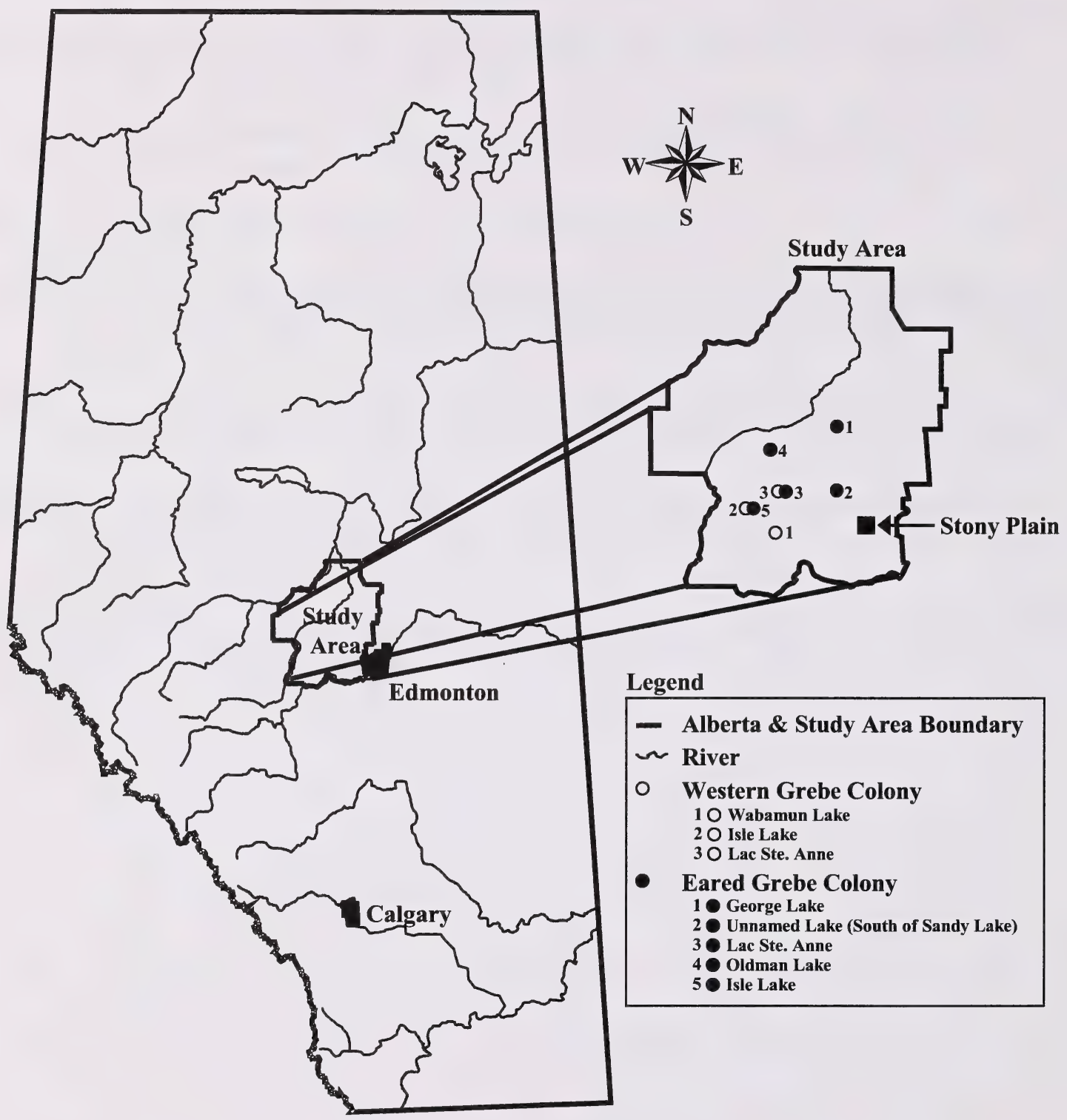




\begin{tabular}{|c|c|c|c|c|c|c|c|c|c|c|}
\hline 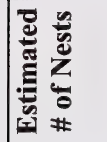 & $\overleftrightarrow{\mathbf{z}}$ & $\widehat{\mathbb{z}}$ & $\overleftrightarrow{\mathbf{z}}$ & 总 & $\frac{\theta}{\infty}$ & $\frac{\mathbb{z}}{\mathrm{z}}$ & $\infty$ & $\frac{\mathbb{z}}{\mathrm{z}}$ & $\overleftarrow{z}$ & \begin{tabular}{|l} 
\\
$\frac{5}{5}$ \\
$\frac{5}{5}$ \\
5
\end{tabular} \\
\hline 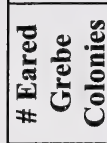 & 这 & 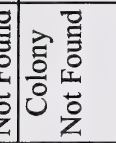 & 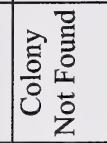 & $m$ & - & 0 & - & 0 & 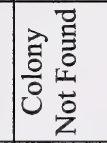 & - \\
\hline 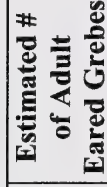 & N & 茍 & $\stackrel{\infty}{\infty}$ & 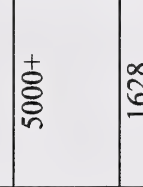 & 跑 & 0 & $\Xi$ & 0 & 喆 & 旁 \\
\hline 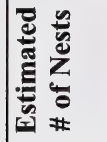 & $\overleftrightarrow{\mathrm{z}}$ & $\frac{\overleftarrow{z}}{z}$ & $\frac{\mathbb{Z}}{\mathrm{z}}$ & $\mathbb{z}$ & ț & $\mathbb{z}$ & $\bar{\sigma}$ & $\frac{\widehat{s}}{z}$ & $\overleftarrow{z}$ & $\widehat{\Sigma}$ \\
\hline 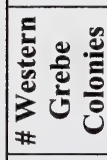 & 0 & 0 & 童言 & 0 & $\sim$ & 㝘言 & - & 0 & 10 & 0 \\
\hline 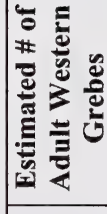 & 0 & 0 & in & 0 & $\stackrel{ \pm}{ \pm}$ & 壱 & ర్ల & 10 & 0 & 10 \\
\hline 突咅 & 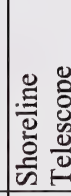 & 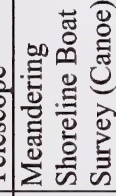 & 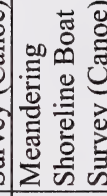 & 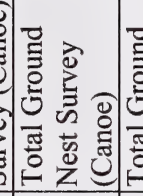 & 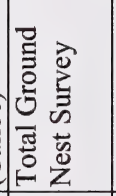 & 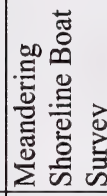 & 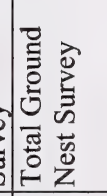 & 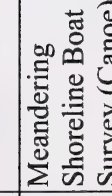 & 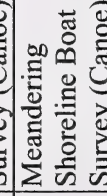 & 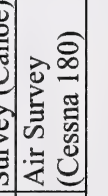 \\
\hline 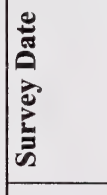 & 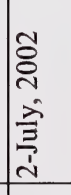 & 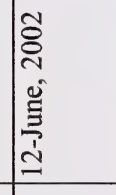 & 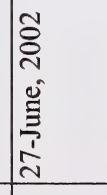 & 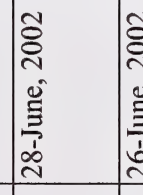 & 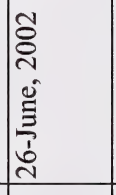 & 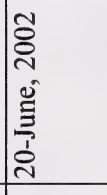 & 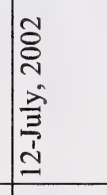 & 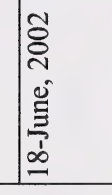 & 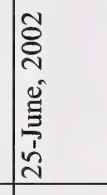 & 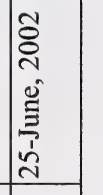 \\
\hline 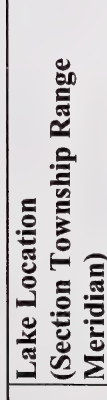 & 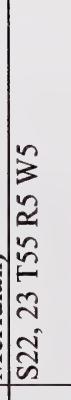 & 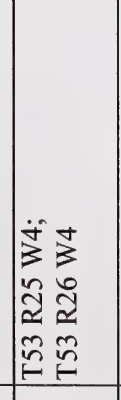 & 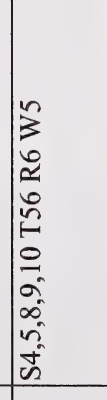 & 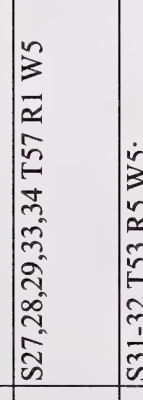 & 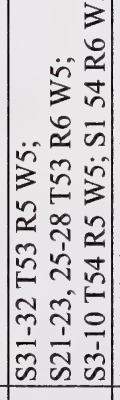 & 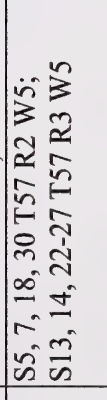 & 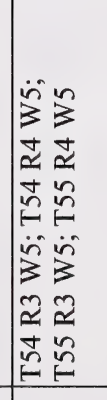 & & 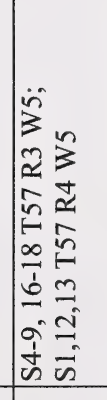 & 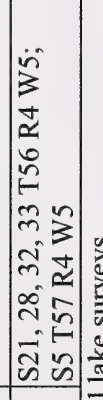 \\
\hline$\frac{\$}{9}$ & 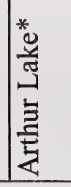 & 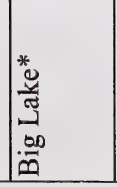 & 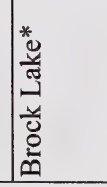 & $\mid$ & \begin{tabular}{|l}
$\frac{0}{3}$ \\
$\frac{0}{0}$ \\
$\frac{0}{\underline{D}}$
\end{tabular} & 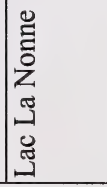 & 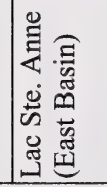 & 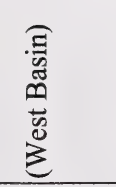 & 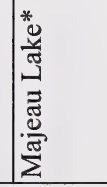 & 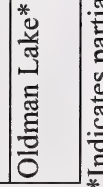 \\
\hline
\end{tabular}




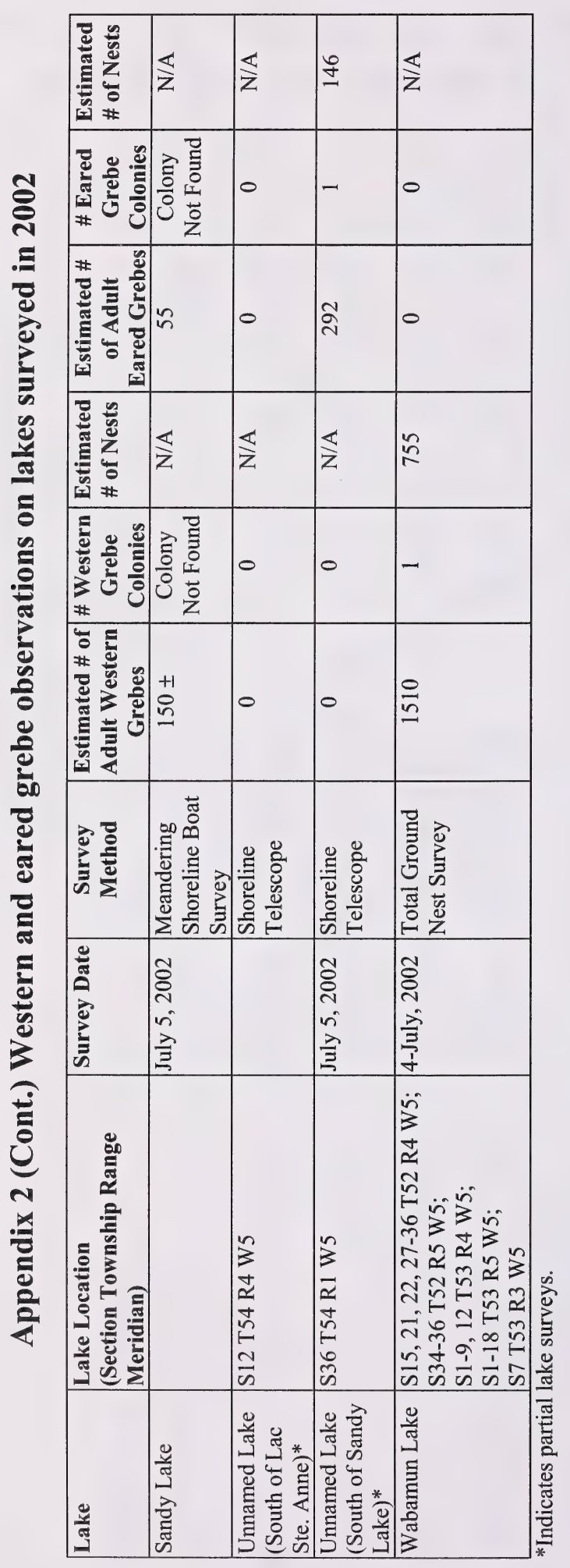




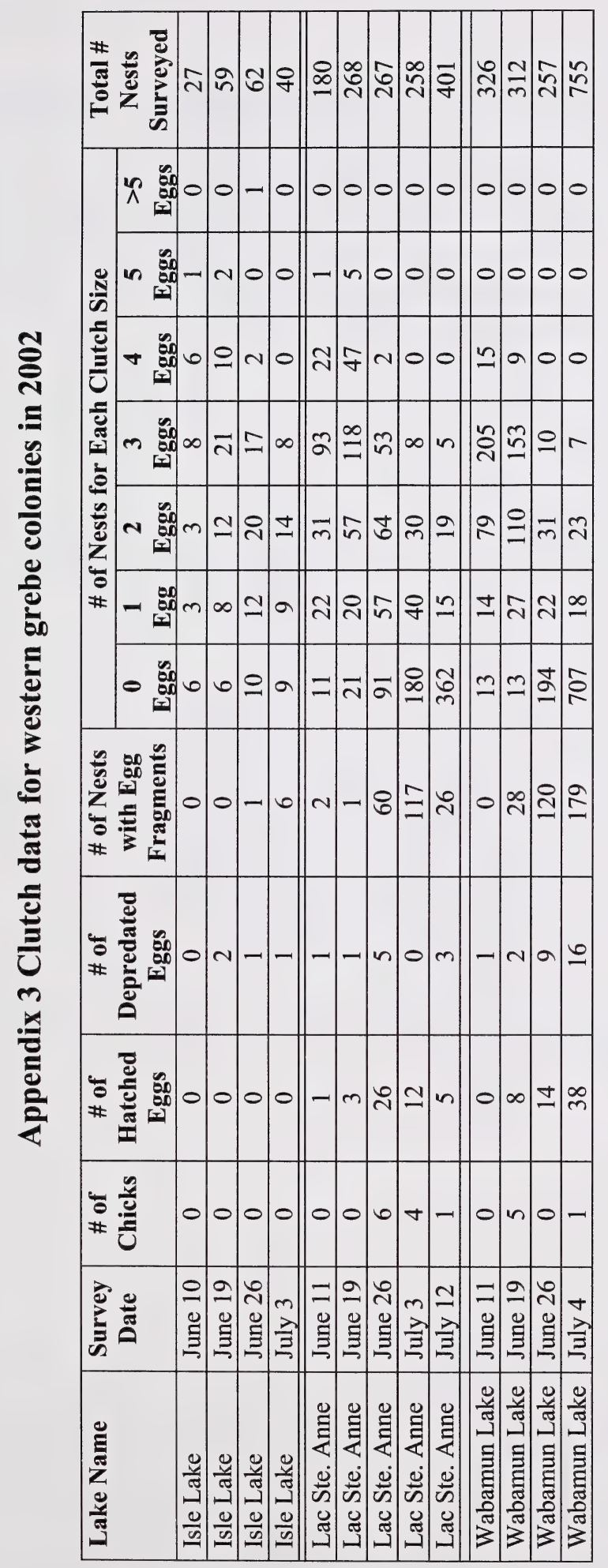




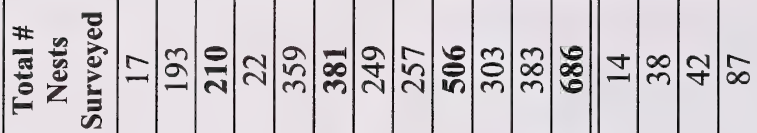

œ

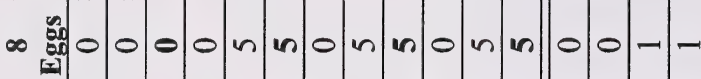

-

站

을

0

n

.

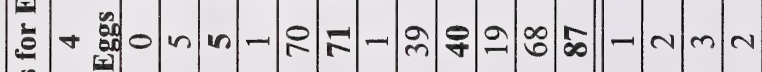

m

$\bar{c}$

ง

-

-

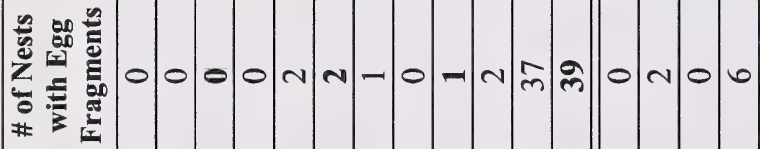

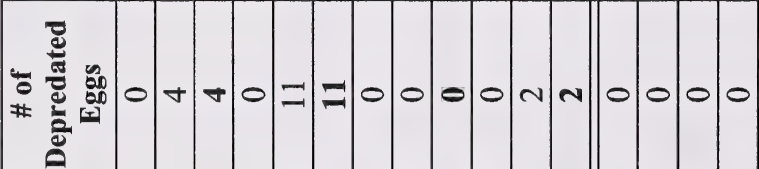

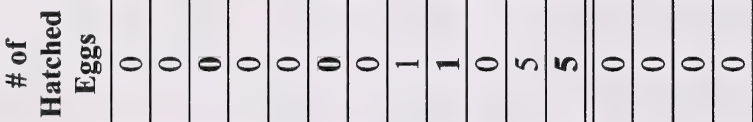

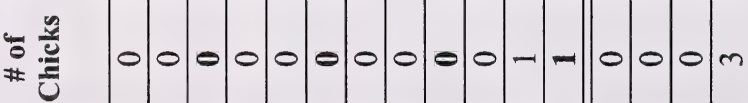

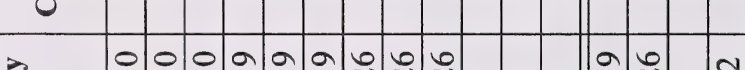

릴

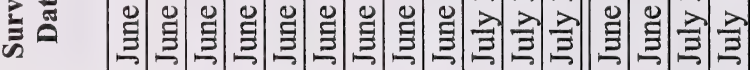

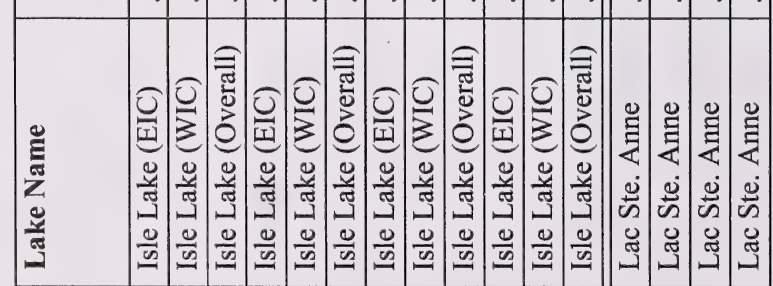


Appendix 5 Western grebe nest quality during post breeding season total nest counts

\begin{tabular}{|l|c|c|c|c|c|}
\hline Lake & Date & $\begin{array}{c}\text { Total \# of } \\
\text { Nests }\end{array}$ & $\begin{array}{c}\text { \# of Intact } \\
\text { Nests }\end{array}$ & $\begin{array}{c}\text { \# of Partially } \\
\text { Submerged Nests }\end{array}$ & $\begin{array}{c}\text { \# of Submerged } \\
\text { Nests }\end{array}$ \\
\hline Lac Ste Anne & 12-July, 2002 & 401 & 133 & 255 & 13 \\
\hline Wabamun & 4-July, 2002 & 755 & 527 & 207 & 21 \\
\hline
\end{tabular}


Appendix 6 Western grebe sign developed for lakes within the Stony Plain study area

\section{HELP PROTECT WILDLIFE AND THEIR HABITAT}

Reeds provide habitat for a wide variety of wildlife including fish and waterbirds. This lake is home to a nationally significant colony of western grebes. They build floating nests among reeds and are extremely vulnerable to disturbance.

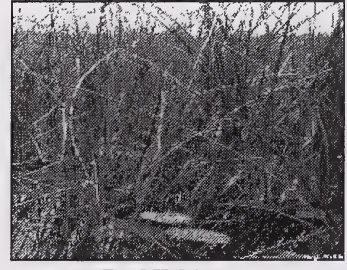

Reed $\mathrm{Hab}$ itat

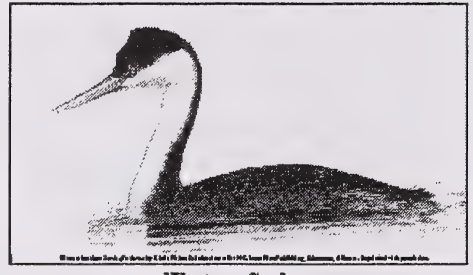

Western Grebe

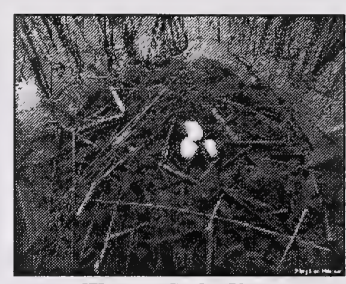

Western Greb e Nest

To help conserve these sensitive birds, other wildlife, and shoreline habitat, please:

- Avoid disturbing and destroying reed habitat.

- Stay a minimum of $100 \mathrm{~m}$ from reed beds and respect speed limits when boating.

Under the Migratory Bird Regulations, it is unlawful to harass, disturb, hunt, capture or kill any migratory bird, or disturb/destroy its nest and eggs. 
Appendix 7 Shoreline habitat sign developed for lakes within the Stony Plain study area

\section{HELP PROTECT WILDLIFE AND THEIR HABITAT}

WaterBirds
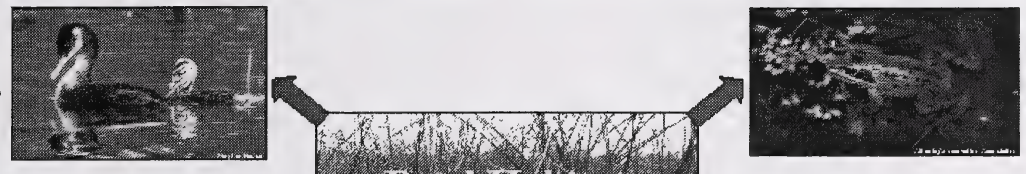

Amphibians

Insects
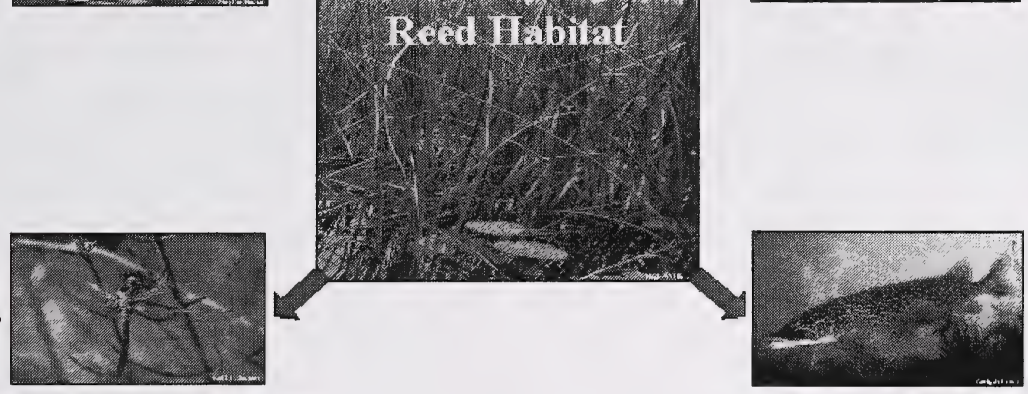

Fish

Reeds provide critical habitat for a wide variety of wildlife.

To help conserve wildlife and shoreline habitat, please:

- Avoid disturbing and destroying reed habitat.

- Stay a minimum of $100 \mathrm{~m}$ from reed beds and respect speed limits when boating. 
Appendix 8 Locations and style of signs established within the Stony Plain study area

\begin{tabular}{|l|l|l|}
\hline Lake & Public Boat Launch & Sign Style \\
\hline \multirow{2}{*}{ ssle Lake } & Hoffman Beach & Shoreline Habitat Conservation \\
\cline { 2 - 3 } & Woodland Bay & Shoreline Habitat Conservation \\
\hline Lac La Nonne & William's Beach & Shoreline Habitat Conservation \\
\hline Lac Ste Anne & Corsair Cove & Shoreline Habitat Conservation \\
\cline { 2 - 3 } & Gunn County Dock & Western Grebe Conservation \\
\cline { 2 - 3 } & Warwa Beach & Shoreline Habitat Conservation \\
\hline Nakamun Lake & Four Oaks & Shoreline Habitat Conservation \\
\hline Thunder Lake & Thunder Lake Provincial Park & Shoreline Habitat Conservation \\
\hline Wabamun Lake & Seba Beach & Western Grebe Conservation \\
\cline { 2 - 3 } & Town of Wabamun Lake & Western Grebe Conservation \\
\cline { 2 - 3 } & Wabamun Lake Provincial Park & Shoreline Habitat Conservation \\
\hline
\end{tabular}




\section{Appendix 9 Specifications for western grebe and shoreline habitat conservation signs}

Sign Size: 2 'x3'

Sign Material: Dibond (two ply sheet metal)

Posts: $10^{\prime}$ metal sign posts cut into $3^{\prime}$ and 7 ' sections

3 ' section driven into ground 2 '

1'overlap with 3' and 7' sections

2 posts per sign

Hardware: Stainless steel nuts, bolts, washers to prevent rust lines on the sign

Regular zinc plated hardware to attach the 3 ' and 7 ' sections of sign posts

Clear silicone was used around the hardware

Graphics: Full colour digital print 


\section{Appendix 10 Grebe and shoreline habitat conservation presentations given to the public}

\begin{tabular}{|l|l|l|l|}
\hline Date & Location & $\begin{array}{l}\text { Audience } \\
\text { (Event) }\end{array}$ & $\begin{array}{l}\text { \# in } \\
\text { Attendance }\end{array}$ \\
\hline Jan. 17, 2002 & $\begin{array}{l}\text { Camp He Ho Ha } \\
\text { Isle Lake, AB }\end{array}$ & $\begin{array}{l}\text { Local Cottagers and Ranchers } \\
\text { (Annual Meeting) }\end{array}$ & 100 \\
\hline Mar. 8, 2002 & $\begin{array}{l}\text { Coast Edmonton Plaza Hotel } \\
\text { Edmonton, AB }\end{array}$ & $\begin{array}{l}\text { Biologists and Students } \\
\text { (Alberta Chapter of the Wildlife } \\
\text { Society Annual Meeting) }\end{array}$ & 50 \\
\hline May 4, 2002 & Isle Lake Community Hall, AB & $\begin{array}{l}\text { Local Residents of Isle Lake Area } \\
\text { (Lake Isle Aquatic Society General } \\
\text { Meeting) }\end{array}$ & 50 \\
\hline July 13, 2002 & S.V of Sunset Point (Lac Ste. Anne), AB & $\begin{array}{l}\text { S.V. of Sunset Point Residents } \\
\text { (General Meeting) }\end{array}$ & 30 \\
\hline Oct.18, 2002 & $\begin{array}{l}\text { NAIT } \\
\text { Edmonton, AB }\end{array}$ & $\begin{array}{l}\text { Edmonton Bird Club Members } \\
\text { (General Meeting) }\end{array}$ & 25 \\
\hline TBA & $\begin{array}{l}\text { Wabamun Lake Power Generating Plant } \\
\text { Wabamun Lake, AB }\end{array}$ & $\begin{array}{l}\text { Management Staff of TransAlta } \\
\text { Utilities }\end{array}$ & N/A \\
\hline
\end{tabular}




\section{List of Titles in This Series}

(as of December 2002)

No. 1 Alberta species at risk program and projects 2000-2001, by Alberta Sustainable Resource Development, Fish and Wildlife Division. (2001)

No. 2 Survey of the peregrine falcon (Falco peregrinus anatum) in Alberta, by R. Corrigan. (2001)

No. 3 Distribution and relative abundance of the shortjaw cisco (Coregonus zenithicus) in Alberta, by M. Steinhilber and L. Rhude. (2001)

No. 4 Survey of the bats of central and northwestern Alberta, by M.J. Vonhof and D. Hobson. (2001)

No. 52000 survey of the Trumpeter Swan (Cygnus buccinator) in Alberta, by M.L. James and A. James. (2001)

No. 6 2000/2001 Brassy Minnow inventory at Musreau Lake and outlet, by T. Ripley. (2001)

No. 7 Colonial nesting waterbird survey in the Northwest Boreal Region - 2000, by M. Hanneman and M. Heckbert. (2001)

No. 8 Burrowing owl trend block survey and monitoring - Brooks and Hanna areas, by D. Scobie and R. Russell. (2000)

No. 9 Survey of the Lake Sturgeon (Acipenser fulvescens) fishery on the South Saskatchewan River, Alberta (June-September, 2000), by L.A. Winkel. (2000)

No. 10 An evaluation of grizzly bear-human conflict in the Northwest Boreal Region of Alberta (19912000) and potential mitigation, by T. Augustyn. (2001)

No. 11 Harlequin duck monitoring in the Northern East Slopes of Alberta: 1998-2000 preliminary results, by J. Kneteman and A. Hubbs. (2000)

No. 12 Distribution of selected small mammals in Alberta, by L. Engley and M. Norton. (2001)

No. 13 Northern leopard frog reintroduction. Raven River - Year 2 (2000), by K. Kendell. (2001)

No. 14 Cumulative effects of watershed disturbances on fish communities in the Kakwa and Simonette watersheds. The Northern Watershed Project. Study 3 Progress report, by T. Thera and A. Wildeman. (2001)

No. 15 Harlequin duck research in Kananaskis Country in 2000, by C.M. Smith. (2001)

No. 16 Proposed monitoring plan for harlequin ducks in the Bow Region of Alberta, by C.M. Smith. (2001)

No. 17 Distribution and relative abundance of small mammals of the western plains of Alberta as determined from great horned owl pellets, by D. Schowalter. (2001)

No. 18 Western blue flag (Iris missouriensis) in Alberta: a census of naturally occurring populations for 2000 , by R. Ernst. (2000)

No. 19 Assessing chick survival of sage grouse in Canada, by C.L. Aldridge. (2000)

No. 20 Harlequin duck surveys of the Oldman River Basin in 2000, by D. Paton. (2000) 
No. 21 Proposed protocols for inventories of rare plants of the Grassland Natural Region, by C. Wallis. (2001)

No. 22 Utilization of airphoto interpretation to locate prairie rattlesnake (Crotalus viridis viridis) hibernacula in the South Saskatchewan River valley, by J. Nicholson and S. Rose. (2001)

No. 23 2000/2001 Progress report on caribou research in west central Alberta, by T. Szkorupa. (2001)

No. 24 Census of swift fox (Vulpes velox) in Canada and Northern Montana: 2000-2001, by A. Moehrenschlager and C. Moehrenschlager. (2001)

No. 25 Population estimate and habitat associations of the long-billed curlew in Alberta, by E.J. Saunders. (2001)

No. 26 Aerial reconnaissance for piping plover habitat in east-central Alberta, May 2001, by D.R.C. Prescott. (2001)

No. 27 The 2001 international piping plover census in Alberta, by D.R.C. Prescott. (2001)

No. 28 Prairie rattlesnake (Crotalus viridis viridis) monitoring in Alberta - preliminary investigations (2000), by S.L. Rose. (2001)

No. 29 A survey of short-horned lizard (Phrynosoma hernandesi hernandesi) populations in Alberta, by J. James. (2001)

No. 30 Red-sided garter snake (Thamnophis sirtalis parietalis) education and relocation project - final report, by L. Takats. (2002)

No. 31 Alberta furbearer harvest data analysis, by K.G. Poole and G. Mowat. (2001)

No. 32 Measuring wolverine distribution and abundance in Alberta, by G. Mowat. (2001)

No. 33 Woodland caribou (Rangifer tarandus caribou) habitat classification in northeastern Alberta using remote sensing, by G.A. Sanchez-Azofeifa and R. Bechtel. (2001)

No. 34 Peregrine falcon surveys and monitoring in the Parkland Region of Alberta, 2001, by R. Corrigan. (2002)

No. 35 Protocol for monitoring long-toed salamander (Ambystoma macrodactylum) populations in Alberta, by T. Pretzlaw, M. Huynh, L. Takats and L. Wilkinson. (2002)

No. 36 Long-toed salamander (Ambystoma macrodactylum) monitoring study in Alberta: summary report 1998-2001, by M. Huynh, L. Takats and L. Wilkinson. (2002)

No. 37 Mountain plover habitat and population surveys in Alberta, 2001, by C. Wershler and C. Wallis. (2002)

No. 38 A census and recommendations for management for western blue flag (Iris missouriensis) in Alberta, by R. Ernst. (2002)

No. 39 Columbian mountain amphibian surveys, 2001, by D. Paton. (2002)

No. 40 Management and recovery strategies for the Lethbridge population of the prairie rattlesnake, by R. Ernst. (2002) 
No. 41 Western (Aechmophorus occidentalis) and eared (Podiceps nigricollis) grebes of central Alberta: inventory, survey techniques and management concerns, by S. Hanus, H. Wollis and L. Wilkinson. (2002)

No. 42 Northern leopard frog reintroduction - year 3 (2001), by K. Kendell. (2002)

No. 43 Survey protocol for the northern leopard frog, by K. Kendell. (2002)

No. 44 Alberta inventory for the northern leopard frog (2000-2001), by K. Kendell. (2002)

No. 45 Fish species at risk in the Milk and St. Mary drainages, by RL\&L Environmental Services Ltd. (2002)

No. 46 Survey of the loggerhead shrike in the southern aspen parkland region, 2000-2001, by H. Kiliaan and D.R.C. Prescott. (2002)

No. 47 Survey of native grassland butterflies in the Peace parkland region of northwestern Alberta - 2001, by M. Hervieux. (2002)

No. 48 Caribou range recovery in Alberta: 2001/02 pilot year, by T. Szkorupa. (2002)

No. 49 Peace parkland native grassland stewardship program 2001/02, by A. Baker. (2002)

No. 50 Carnivores and corridors in the Crowsnest Pass, by C. Chetkiewicz. (2002)

No. 512001 Burrowing owl trend block survey and monitoring, Brooks and Hanna areas, by D. Scobie. (2002)

No. 52 An evaluation of the ferruginous hawk population in Alberta based on recent trend data, by D.P. Stepnisky, G.L. Erickson, J. Iwaasa and B. Taylor. (2002)

No. 53 Alberta amphibian call surveys. A pilot year. Final report, by L. Takats and C. Priestley. (2002)

No. 54 Utilization of a roadside survey technique to survey burrowing owl (Athene cunicularia hypugaea) in southeastern Alberta, by J. Nicholson and C. Skiftun. (2002)

No. 55 Alberta species at risk program and projects 2001-2002, by Alberta Sustainable Resource Development, Fish and Wildlife Division. (2002)

No. 56 Developing a habitat-based population viability model for greater sage-grouse in southeastern Alberta, by C.L. Aldridge. (2001)

No. 57 Peregrine falcon surveys and monitoring in the Northeast Boreal Region of Alberta, 2001, by R. Corrigan. (2002)

No. 582002 burrowing owl trend block survey and monitoring, Brooks area, by R.F. Russell. (2002)

No. 59 Rare plant inventory of the eastern edge of the lower foothills natural subregion, west-central Alberta, by J. Doubt. (2002)

No. 60 Western (Aechmophorus occidentalis) and eared (Podiceps nigricollis) grebes of central Alberta: 2002 field summary, by S. Hanus, H. Wollis and L. Wilkinson. (2002)

No. 61 Inventory of western spiderwort (Tradescantia occidentalis) in Alberta: 2002, by S. Peters. (2003) 


National Library of Canada
Bibliotheque nationale du Canada

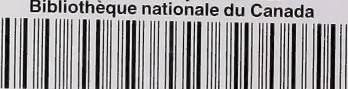

33286527364117 